\title{
THE PRESERVATION OF OPEN SPACE IN METROPOLITAN AREAS *
}

\section{JAN Z. KRASNOWIECKI $\dagger$ aND JAMES C. N. PaUL $\ddagger$}

After precarious progress through Congress, a truncated version of an Administration measure for federal aid to state and local programs for the preservation of open space became Title VII of the Federal Housing Act of $1961 .^{1}$ It authorizes expenditures up to $\$ 50,000,000$ "to help finance the acquisition of title to, or other permanent interests" in "open-space land" located "in urban areas." 2

The enactment of Title VII - which was probably a minor political miracle-should focus more attention on one of the most urgent, yet in some senses unfamiliar, of our metropolitan problems. This is the first significant legislation designed to help urban regions secure openspace areas. Federal aid may be so important to the solution of this problem that the goals expressed by this statute, the legal devices to secure them, and the requirements for grants-in-aid may set a pattern for immediate state and local action. ${ }^{3}$

Unfortunately, Title VII is limited to the use of traditional devices for the accomplishment of essentially new goals, and, unfortunately, as finally enacted, it takes a limited view of the goals themselves. This may discourage development of new devices to accomplish bolder, but not necessarily more expensive, programs in the struggle

* Ann Louise Strong, a member of the Philadelphia bar, cooperated with the authors in preparing an earlier memorandum on this subject, including a draft of the legislative proposals which are published as an Appendix to this Article. While not an author of this Article or the revised legislative proposals, nor responsible for all of the judgments made herein, she rendered indispensable aid to the development of the project and in that sense is a coauthor. Professor Paul Davidoff of this University has helped one of the authors in particular by giving extensive time to discussion of some of the problems considered in the text.

The funds to defray the costs of this project were supplied by PenJerDel Inc. and the Institute of Iegal Research of the University of Pennsylvania Law School. The viewpoints are the authors' and should not be attributed to anyone else.

† Assistant Professor of Law, University of Pennsylvania. B.A. 1951, B.C.L. 1952, M.A. 1955, Oxford; LL.M. 1956, Harvard University.

$\$$ Professor of Law and Director of the Institute of Legal Research, University of Pennsylvania. A.B. 1948, Princeton University; LL.B. 1951, University of Pennsylvania.

175 Stat. 183 (1961).

2 Housing Act of 1961, $\S \S 702$ (a), (b), 706(1)-(2), 75 Stat. 184, 185 (1961).

3 Our prognostication seems to have been fulfilled in Pennsylvania by the enactment on September 16, 1961, of a law broadly authorizing land-use studies and purchase and acceptance of land for purposes substantially identical to those expressed in Title VII, and enabling the state, its agencies, political subdivisions, and local public bodies to accept funds and other assistance for these purposes from the federal government and other sources. $\mathrm{Pa}$. Laws 1961, act 614. See note 122 infra. 
with the "exploding metropolis." We attempt in this Article to present some criticisms of the existing devices and some proposals for a new approach-proposals which still need to be worked out more fully in their detail. Our "criticism" of some measures brilliantly advocated by others will not, we hope, be misconstrued. If Americans succeed, as we devoutly hope they will, in formulating programs to save our vanishing metropolitan open space, it will be due in major part to the efforts of a few who have labored hard to explain needs, arouse legislative interest, and secure passage of pioneer laws like Title VII. We present our views now because we are concerned lest the passage of the federal measure and hasty state responses to it, postpone indefinitely the kind of controversy, as to goals and as to means, which may lead to a more effective definition and solution of the problem of open spaces.

\section{Needs, Objectives, and Assumptions}

The premise for all open-space legislation is that much undeveloped land in and around an expanding metropolis is an increasingly valuable asset. ${ }^{4}$ Open areas should be preserved for a variety of purposes, economic and otherwise-some only vaguely articulated thus far: to "shape" or "time" urban growth and thus prevent development from spreading at all, or too fast, into areas where it will produce high public cost for community services or hasty, ill-planned sprawl today which will be blight tomorrow; to preserve nature and natural amenities; to relieve urban congestion and create more cohesive suburban communities; to reserve large accessible areas for outdoor recreation and neighborhood playgrounds and parks; to preserve sites of historic or scientific importance; to conserve wildlife habitats, water supply areas, valuable forests, and agricultural land; to minimize water runoff, soil erosion, and flood damage in critical areas; to protect health against the hazards of inadequate waste disposal; and to reserve adequate land for the development of facilities, public or private, that careful estimates suggest will be needed in the future.

The importance of defining these functions precisely-of deciding what we wish to achieve through conservation of open space-cannot be overstressed. For the legal approach to the preservation of open space may vary significantly according to the goals one conceives. ${ }^{5}$ This

4 For a discussion of the needs for urban open space, see generally CLAwson, Held \& Stoddard, Land for the Future (1960); Siegel, The Law of Open Space (1960); Whyte, Securing Open Space for Urban America: Conservation EASEMENTS (Úrban Land Inst. Tech. Bull. No. 36, 1959).

5 Thus, if the purpose is simply to facilitate the rapid acquisition of the best and most needed park and conservation areas within a state, then a study might survey the needs of a state as a whole and focus on powers to be given to state and local 
Article concentrates on the problem of fashioning legal devices to implement two general categories of open-space projects.

\section{A. Metropolitan Green Areas ("Greenbelts")}

We believe there is a need for integrated, multi-purpose openspace projects which will insure the preservation of large and presently undeveloped areas within and around our burgeoning cities. The function of these areas might be in part to secure the economies attendant upon channeling later development into areas better suited and more carefully planned for it, in part to fulfill the needs of recreation, conservation, and water supply, in part to provide open areas for the aesthetic and related values which access to natural surroundings brings to the lives of urban dwellers, in part to separate distinct communities, if this would be to their advantage, and in part to reduce other undesired effects of continuous, intensive land use. ${ }^{8}$ Hypothetically, such an area might cover several square miles, though it could be somewhat smaller or considerably larger; it might traverse municipal and county boundaries. It might include undeveloped sections of a stream valley, land which is ill-suited for intensive development, or land valued for its potential recreational and scenic value. The planning of the openspace project might contemplate that most of the area would remain in private use. We assume, as spelled out elsewhere, that properties within the area would remain freely transferable and that governmental action to guarantee the "openness" of these lands would enhance their market value for private use and encourage farming and other employments compatible with the project's objectives. But some of the land might be converted to public ownership and some private lands might be used, through the acquisition of interests in the nature of easements or licenses, for conservation, water storage, or outdoor

park agencies, on devices to provide massive funds, and on provisions to promote speedy comprehensive planning, close cooperation between state and local units, and fast reservation of desirable sites throughout the state by using a variety of techniques for acquisition or land reservation. If the purpose is mainly to secure more small neighborhood parks and open areas within existing built-up areas, then attention might focus on the use of urban renewal and redevelopment powers, on the acquisition of tax delinquent lands, and on the imposition of subdivision controls, to promote the result. If the goal is water resources development, then we might survey a different geographical area, concentrating on fashioning tools for a state or bistate agency to acquire sites for dams and on zoning to protect critical runoff areas and flood plains. If the purpose is to provide more open areas within or about new residential developments, then study might focus on cluster zoning, on subdivision regulations, and on devices to promote public use and inexpensive maintenance of some of these lands in order to reduce community costs. If the purpose is to provide large open areas to "shape" development of the metropolis and secure other assumed economic and aesthetic advantages suggested above, then one must probably consider different, more novel legal means.

"The "greenbelt" is, of course, an important concept in England. See 2 Town and Country Planning 4192 (Heap ed. 1959). 
recreation. Experimentation with the British park concept, where portions of large private land holdings have been converted to a limited public use, may be advisable-particularly when one takes account of expenditures, tax losses, and other factors which may make acquisition and maintenance of large publicly owned park areas prohibitively expensive.

\section{B. Reservation of Land for Later Development}

A second objective which we hypothesize is this: There may be a need to retard temporarily the development of some metropolitan land areas because of a lack of adequate facilities to service them or because it is contemplated that their present development will thwart an existing comprehensive plan for the location of facilities which the community will need in later years. Again, we are assuming that the land in question is a substantial area and that the need to retard development can be shown to be urgent.

Both categories of open-space projects can and should serve economic purposes-to save public costs or to preserve land of great economic importance. By requiring an economic objective as well as other purposes, one may present a more persuasive case, in terms of both practical politics and the avoidance of constitutional limitations. A required economic purpose may also help to supply concrete standards to guide community planners. If data cannot be marshalled to show that the preservation of an open-space area will reduce costs and promote long-term economies in the public sector, then the desirability of many projects and perhaps, too, the philosophy of the underlying enabling legislation may be open to serious question.

Of course the assumptions and objectives posited here may be untenable. As lawyers, we have labored somewhat in the dark. Thus far, there has been perhaps too little precise articulation of open-space objectives and research to demonstrate their need. True, much has been written about park needs in many metropolitan areas, and studies of some areas have identified suggested sites for future facilities, estimated costs, and sounded the call to action. But to some extent each of these studies has ignored other needs and even other ways to secure space for its own narrow purposes. Furthermore, the standards used in park and recreation studies to estimate acreage needs, to identify the type of lands most urgently needed, and to fix criteria of accessibility are perhaps necessarily subjective and $a d h_{0 c}{ }^{7}$ Even more difficult are the arguments that government funds should be spent on

7 See Clawson, Held \& Stoddard, op. cit. supra note 4, at 185-86. 
keeping privately owned land open in order to preserve natural and rural amenities, to provide "relief" from high density envelopment, and generally to create what some may believe would be more desirable patterns of attractive suburban development. These concepts may sound appealing but vague. Whose "community" is to be improved, whose amenities protected, and at how much cost to whom? These questions are sharpened by the dearth of research translating general propositions about goals into concrete projects for particular areas and justifying these projects economically and socially. One must consider all competing claims on public resources available for community improvement; if acquisition of open-space areas will cost inestimable amounts of money (notwithstanding possible eventual savings), should that money be expended if it requires sacrificing other social objectives, such as better schools and better housing? Finally, it must be realized that land itself is a scarce resource; areas allocated for open space may be needed to supply housing or facilities which will broaden local tax bases or serve other purposes.

We do not know the answers to these questions. Judgment may best come from those with expertise we lack. But we do have considerable evidence that open space may be needed to supply facilities or benefits and secure economies which the public may value more and more as development surrounds us more and more. ${ }^{8}$ In any event, it is not our thesis that multipurpose projects of the types described must be undertaken, and certainly not that a large element of discretion to decide that question should be delegated to a small body of experts. Rather, it may be desirable to secure these open-space objectives, and it may be feasible to write laws which will stimulate closer study of possible projects, provide substantive standards which will focus attention on the need to justify planned projects with economic and other data, promote full public discussion of needs, objectives, and priorities, and permit the public to register its will through elected officials of established units of government. Even if we are wrong in our assumptions, we hope at least that by suggesting the kind of projects mentioned above and outlining a new legal way to effect them, others can be prodded to define what should be the open-

8 For evidence of needs and citizen concern, see, e.g., INST. FOR URBAN STUDIES OF the UnIversity of PenNsylvania, Four-County Industriad Land and Facmities ReQuirements (1957); Martin, Birkhead, Burkhead \& MUNGer, RIVEr Basin Adactaistration AND the Delaware (1960); Southeastern Pennsylvania Regional Planning Comman, Regtonal Industriat Land and Facilities (1957); Wheaton \& Schusshetm, The Cost of Municipal. Service in Residential AReas (1955); Fagin, Regulating the Timing of Urban Development, 20 LAW \& CoNTEMr. PROB. 298 (1955); Hearings on Varions Bills to Amend the Federal Honsing Laws Before a Subcommittee of the Senate Committee on Banking and Currency, 87th Cong., 1st Sess. 1002 (1961) (remarks of William H. Whyte, Jr., on citizen support). 
space objectives of metropolitan areas. Then the lawyers can go back to work on the proper ways to secure the ends sought. There may not be much time to waste.

\section{Legal Methods To Secure Open Space}

Assuming the two general objectives stated above-_"greenbelts" and reservation of land for later development-what legal means might best be used to achieve them? We begin by analyzing conventional techniques under the police and eminent domain powers, conclude that they are either inadequate or too expensive for these purposes, and suggest that it is time to stop viewing police power and eminent domain as two mutually distinct, independent, and exclusive ways to secure the result desired. Then, in Part III of this Article, we explore an avenue which to some extent combines both methods, and explain a comprehensive Open-Space Act $^{\theta}$ which we have drafted to regulate land use in the manner of zoning and to guarantee the owner of affected land the value of his property in the manner of eminent domain. Finally, we reconcile this new approach with the "public purpose" doctrine, analyze planning requirements and intergovernmental coordination, suggest substantive, objective standards to govern decision making, and propose a new governmental vehicle to work with federal, state, and existing local units to promote open-space projects.

\section{A. Use of the Police Power}

Land-use controls which can be sustained as noncompensable regulations under the police power are inadequate to accomplish the broader objectives of open-space preservation. The technique that comes closest to controlling land areas large enough to accommodate a comprehensive open-space project is that of the "official map." Its obvious limitations, however, reflect the limitations of any police power approach.

While the term "official map" is not always used in the legislation enabling this technique, the term, as used here, refers to a map, officially adopted, which reflects a municipality's fixed decision to locate streets, parks, and other facilities at the places marked on the map, and to condemn later. The decision is implemented by a prohibition against improvements in areas earmarked for acquisition and enforced by injunctive relief and denial of the right to compensation, on later condemnation, for unauthorized improvements.

9 Appendix, pp. 218-39 infra. 
An early version, confined to mapping of streets, was sustained by the highest court of New York in 1836 as a valid exercise of the police power. ${ }^{10}$ But at that time the state constitution did not contain a provision securing compensation for the taking of private property for public use. After the constitution was amended in this respect, the court of appeals declared the law unconstitutional. ${ }^{11}$ It is not entirely clear from the opinion of the court whether the law was held invalid on its face or merely as applied.

In 1926, after considerable controversy, the New York legislature adopted a modified version of an official map law drafted by Bassett and Williams. Its major innovation was a provision that the owner, upon a showing that his property as mapped cannot "yield a fair return," is entitled to improve to the extent necessary to give him such return. ${ }^{12}$ With the inclusion of this "shock absorber," the New York Court of Appeals, in Headley v. City of Rochester, ${ }^{13}$ sustained the validity of the law and affirmed a decision against an owner on the ground that he had failed to make a showing of injury. More recently, Wisconsin's official map law, ${ }^{14}$ modeled largely after the New York statute, was sustained against a claim that it is unconstitutional on its face. The court stressed, in particular, the "shock absorber" clause.15 The exception provided by this clause was intended by its draftsmen to be more generous to the owner than is the corresponding line drawn in zoning between a "taking" and regulation. Speaking of the provision, Bassett and Williams said:

It has been suggested that the . . provisions . . . needlessly sacrifice the interests of the public to those of the property owner, in that under them the owner may encroach upon the city plan, even if his damage be slight and the public injury great. It is argued that in other regulations, - zoning, for instance,- - actual loss is sometimes suffered by the property owner in the public interest, and the courts sustain this exercise of the police power if, under all the circumstances, they regard it as reasonable. Why should not this be done in

10 In the Matter of Furman Street, 17 Wend. 649, 667 (N.Y. 1836).

11 Forster v. Scott, 136 N.Y. 577, 584-85, 32 N.E. 976, 977 (1893).

12 N.Y. Gen. CitY LAW \& 35 ; see Bassett \& Williams, Report, in MOdeL Laws for Planning Cities, Counties and States 22 (Harvard City Planning Studies No. VII 1935).

13272 N.Y. 197, 5 N.E.2d 198 (1936).

14 Wis. Stat. AnN. $\$ 62.23(6)$ (1957).

15 State ex rel. Miller v. Manders, 2 Wis. 2d 365, 86 N.W.2d 469 (1957). Compare the Pennsylvania provision for mapped streets, PA. STAT. ANN. tit. 53, \&14133 (1957), which does not give the owner the right to improve, even if he can show that his property, as mapped, cannot yield a "reasonable return." See Philadelphia Parkway Opening, $295 \mathrm{~Pa}$. 538, 145 Atl. 600 (1929); In re Sansom St., $293 \mathrm{~Pa} .483,143$ Atl. 134 (1928). These cases, while they approve of the statute, indicate that the approval is confined to cases in which the owner is not too seriously injured. For an excellent full discussion of the official map technique, see Kucirek \& Beusher, $W$ isconsin's Official Map Law, 1957 Wrs. L. Rev. 176. 
the protection of mapped streets? Without discussing the constitutionality of a provision drawn from this point of view, we say that at this time we feel that reasonable provision for adjustment, to minimize claims of unnecessary hardship, is the wisest policy. ${ }^{16}$

Despite this intended generosity, the legislatures of New York and Wisconsin limited the enforcement clause prohibiting development to areas mapped for streets and highways, ${ }^{17}$ although both laws authorize the mapping of future parks and playgrounds. ${ }^{18}$

New Jersey, however, in its comprehensive revision of planning laws in 1953, extended the prohibition to planned parks and playgrounds, but limited its effect as to parks and playgrounds to one year from the application for plat approval. ${ }^{19}$ This limitation was included notwithstanding that the prohibition is subject to the owner's right to develop if he can show that his property "cannot yield a reasonable return ...." 20 Senate bill 651, introduced in the last session of the Pennsylvania legislature, also extends the moratorium to planned parks and playgrounds and similarly limits it to one year after application for a building permit or formal notice to the governing body of an intention to develop. ${ }^{21}$

Thus, despite the fact that the right secured to the owner to develop where he can show that his property cannot yield a reasonable or fair return was intended to be more generous to him than would be the court-developed line between "regulation" and "taking," the official map moratorium on development has either not been extended to larger areas such as parks and playgrounds or, if extended to such areas, has been limited to one year. While this does not prove the unconstitutionality of an indefinite moratorium applied to such areas, coupled with a right in the owner to develop if his property cannot yield a reasonable return, it is persuasive evidence of the present state of opinion on this subject.

In Miller v. City of Beaver Falls, ${ }^{22}$ the Pennsylvania Supreme Court held invalid on its face a statute which sought to bar for three years all incompatible development in areas mapped for future parks, giving the municipality that period of grace to make up its mind, budget the improvement, and buy the land. The court swept aside all arguments that the three-year period was not too much of a hardship

16 Bassett \& Williams, supra note 12, at 24.

17 N.Y. Gen. City Law \$ 35; Wis. Stat. Ann. \$62.23(6) (d) (1957).

18 N.Y. GEN. City LAW § 26; WIS. STAT. ANN. $\$ 62.23$ (6) (a) (1957).

19 N.J. Stat. AnN. \& 40:55-1.32 (Supp. 1960).

20 N.J. Stat. ANN. \$ 40:55-1.38 (Supp. 1960).

$21 \mathrm{~Pa}$ S. 651, §406, as amended (1961).

$22368 \mathrm{~Pa} .189,82$ A.2d 34 (1951). 
to the property owner and that the law served urgent public needs to facilitate planning and finance recreation projects. The law, it is true, did not entitle the owner to develop where he could show that his property could not yield a reasonable return. But even with such an exception, there would probably be serious objections to any attempt to prohibit most development for the sustained periods necessary to accomplish the type of open-space objectives envisaged in this Article.

From a functional point of view, the whole scheme would be threatened by giving the owner a right to develop whenever he can show that his land "cannot yield a reasonable return." The objectives of open-space planning should not be exposed to patchwork disruption resulting from such an exception. In most cases, the community would have to meet each successful claim to develop with condemnation at values inflated by the unspoiled character of surrounding properties.

Even the draftsmen of the prototype official map law recognized that the exception is sufficiently vague to permit some give-and-take when the owner claims his right to develop. For example, they state that if an owner wants to build a four-story masonry building across a mapped street, the language of the exception might permit the building department to insist that the structure be only one story high and of inexpensive material, if that will yield a "reasonable return." 23 This flexibility not only spells constant friction and litigation but may be quite objectionable on other grounds.

Very recently the Supreme Court of Pennsylvania held invalid a "flexible selective zoning" provision of a township ordinance. ${ }^{24}$ The court rested its decision principally on the grounds that the ordinance vested too much discretion in the township supervisors ${ }^{25}$ and that the applicant-by-applicant method of designating zones contemplated by the ordinance was the very "antithesis of zoning 'in accordance with a comprehensive plan." "26 Both these objections spell difficulties for the "reasonable return" clause of the official map law, in view of the vagueness of its language and the function assigned to it by its draftsmen.

An indefinite moratorium on development subject only to the right of the owner to a "variance"-as in the case of zoning-would almost certainly fail of constitutional validity. ${ }^{27}$ It is true that courts

23 Bassett \& Williams, supra note 12 , at 22 .

24 Eves v. Zoning Board of Adjustment, $401 \mathrm{~Pa} .211,164$ A.2d 7 (1960).

25 Id. at $217-18,164$ A.2d at $10-11$.

26 Ibid.; see Haar \& Hering, The Lower Gwynedd Township Case: Too Flexible Zoning or an Inflexible Judiciary?, 74 HARV. L. REV. 1552 (1961).

27 See Vernon Park Realty, Inc. v. City of Mount Vernon, 307 N.Y. 493, 121 N.E.2d 517 (1954); cf. In re Lower Moreland Township Ordinance, 81 Pa. D. \& C. 387 (Quarter Sess. Ct. 1951) (dictum that compulsory dedication is unconstitutional); Comment, 1961 Wrs. L. REV. 310. 
have sustained a good many low-density zoning ordinances in suburban communities. But a careful study of the cases sustaining lot size minima of one, two, even five acres, reveals that in none of them was profitable development found to be impossible. ${ }^{28}$ In fact, it seems that such minima do not significantly discourage development. ${ }^{29}$ Little comfort can be found in the fact that imposition of the larger minima is sometimes attended by litigation. It is suspected that such litigation merely expresses the disappointment of developers who are organizationally geared to low-cost housing or of private owners who are not prepared to accept any delay in profitable sale for development. The only clear effect of larger minima appears to be to assure that the development will be of the sort which is beyond the financial means of a substantial portion of the population. ${ }^{30}$ In short, this method of preserving open space may have an ironic tendency to dot the countryside with relatively inaccessible homes, increasing the burden on public facilities both locally and in the metropolitan region as a whole. Even if low-density zoning ordinances of sufficient stringency to prevent development inimical to open-space purposes were sustained today, it seems clear that as "circumstances" change the validity of the zoning could and should be reviewed. ${ }^{31}$ This would again result in endless disruption of open-space objectives.

The cases give little encouragement to the employment of zoning for the purpose of preserving open space for the development of future private or public facilities. Reservation for future private use implies that there is no present market for such use. It would seem to follow that the zoning must be attended by substantial hardship to the owner. Accordingly, the courts, while professing respect for the provident foresight of the town fathers, have been unwilling to tie down the owner unless the reserved uses have been shown to be imminent. ${ }^{32}$

28 See, e.g., Senior v. Zoning Comm'n, 146 Conn. 531, 153 A.2d 415 (1959); Simon v. Town of Needham, 311 Mass. 560 , 42 N.E.2d 516 (1942) ; Levitt v. Incorporated Village of Sands Point, 6 N.Y.2d 269, 160 N.E.2d 501, 189 N.Y.S.2d 212 (1959); Bilbar Constr. Co. v. Board of Adjustment, $393 \mathrm{~Pa}$. 62, 141 A.2d 851 (1958); cf. Lionshead Lake, Inc. v. Township of Wayne, 10 N.J. 165, 89 A.2d 693 (1952). But see Medinger Appeal, 377 Pa. 217, 104 A.2d 118 (1954).

29 See Mass. Dep'T of Commerce \& Urbain Affairs \& M.I.T. Regronal Studies Section, The Effects of Large Lor Size on Residential Development 7-11 (Urban Land Inst. Tech. Bull. No. 32, 1958) (which also contains data on the relation of large lots to municipal costs and to tax valuations).

30 See Mishkin, Are the Established Legal Principles of Zoning Valid and Adequate for Current Conditions of Rapid Metropolitan Growth and Urban Redevelopment?, Munic. L. Serv. Letter, Jan. 1960, p. 1 (1960).

31 See, e.g., Russell v. Board of Adjustment, 31 N.J. 58, 65, 155 A.2d 83, 87 (1959). The very inquiry into the reasonableness of zoning presupposes existing data which might change with the passage of time. See Fischer v. Bedminster Township, 11 N.J. 194, 205, 93 A.2d 378, 384 (1952) (dictum).

32 Corthouts v. Town of Newington, 140 Conn. 284, 289, 99 A.2d 112, 115 (1953); Averne Bay Constr. Co. v. Thatcher, 278 N.Y. 222, 15 N.E.2d 587 (1938); Opgal, 
On the other hand, reservation for future public use is often designed to effect savings on ultimate public acquisition. This is not exclusively the goal, for example, of reservation for future parks. Here what is sought as well is preservation of the natural characteristics which are essential to the public use intended. Preservation of natural characteristics of land, however, implies more burdensome restrictions on development. And Miller $v$. City of Beaver Falls ${ }^{33}$ stands plainly in the path of such restrictions.

Where the future public use does not require the preservation of natural characteristics of land, where it can afford to be more generous to intermediate uses, the principal objective of reservation, surely, is to hold the cost of future acquisition to the minimum. This, however, runs afoul of those cases which hold that a desire to save on future condemnation is not a proper objective of zoning. ${ }^{34}$

Thus, zoning for future private or public use is exposed, at one end, to the objection that its restrictions are too burdensome and, at the other, to the objection that its sole objective is to reduce the cost of acquisition. Some such zoning, no doubt, might slip by these objections, but it would seem to be hardly of the kind that would accomplish the manifold objectives of open-space planning.

In short, the processes familiar in zoning cases-the balancing of the burden upon the individual against the benefit of the community ${ }^{35}$-limit police power techniques to restrictions that are less burdensome than those necessary to the accomplishment of openspace objectives. In addition, police power techniques, even if sustained initially, are not resilient enough to survive subsequent encroachment. These two limitations alone spell endless disruption for an open-space plan attempted through police power regulation.

\section{B. Tax Incentives and Other Consensual Techniques}

A tax abatement system patterned on a recent Massachusetts proposal ${ }^{36}$ serves to illustrate the weaknesses of consensual land reserva-

Inc. v. Burns, 20 Misc. 2d 803, 189 N.Y.S.2d 606 (Sup. Ct. 1959), aff'd, 10 App. Div. 2d 977, 201 N.Y.S.2d 831, aff'd, 9 N.Y.2d 659, 173 N.E.2d 50, 212 N.Y.S.2d 74 (1961). Some courts have even insisted that zoning must reflect present adaptability consistent with public interest and may never look to future adaptability. Frederic v. Jackson County, 197 Miss. 293, 20 So. 2d 92 (1944).

$33368 \mathrm{~Pa} .189,82 \mathrm{~A} .2 \mathrm{~d} 34$ (1951), discussed in text accompanying note 22 supra; see Joint Meeting v. Borough of Middlesex, 173 A.2d 785 (N.J. Super. Ct. 1961). 34 E.g., Kissinger v. City of Los Angeles, 161 Cal. App. 2d 454, 327 P.2d 10 (Dist. Ct. App. 1958) ; Long v. City of Highland Park, 329 Mich. 146, 45 N.W.2d 10 (1950).

35 See Mack v. County of Cook, 11 III. 2d 310, 315, 142 N.E.2d 785, 788 (1957); Hauser v. Arness, 44 Wash. 2d 358, 367-69, 267 P.2d 691, 696-98 (1954). (1959).

36 Mass. H.R. 1681 (1957), reprinted in HaAR, LAND-Use Planning 687-88 
tion techniques. Under this system, undeveloped land may be allocated on the land-use map as open land, and the owners may agree with the local government not to develop it for at least a stated period. In return for that agreement, a certain proportion of real estate taxes are "deferred." The owner must refrain from development for the stated period, and he may continue to enjoy the deferrals after that time, as long as he keeps the land open; but when he does develop, all the accumulated deferrals become due.

While this system might pass muster when tested against constitutional requirements of uniform taxation, ${ }^{37}$ it would have the unfortunate effect of actually attracting development into the area sought to be kept open. For when enough owners have elected to come within the scheme, the property of those who have held out will be enhanced in value for development. This is the ironic result of all consensual schemes for the preservation of open space.

\section{The Development Rights Approach}

No distinction is more familiar in land-use planning than the distinction between noncompensable regulation and "taking." It is drawn in the light of constitutional guarantees that property shall not be taken for public use without just compensation. The attention of legal scholars has, for the most part, focused on the problem of finding some comfortable principle which should govern this distinction. ${ }^{38}$ The search has, on the whole, failed to unearth its quarry and has also diverted attention from one important aspect of the distinctionits practical consequences, once drawn. For example, when a zoning ordinance is invalidated in its application to a particular piece of property, not because it fails to serve a valid public purpose but because its regulation is held to be a "taking" of the property, the result is that there is a lacuna in the ordinance coextensive with the boundaries of the property involved. What, then, is done about this land? The standard answer, which nobody seems to have questioned, is to rezone it. $^{39}$ Apparently it has never been suggested that the zoning authority should have power simply to reenact the original regulation and pay compensation for the "taking" which has resulted. And because

37 E.g., PA. Const. art. IX, $\S 1$; see, e.g., Clearfield Bituminous Coal Corp. v. Thomas, $336 \mathrm{~Pa}$. 572, 9 A.2d 727 (1939). For a detailed review of cases on tax uniformity, see Newhouse, Constitutional UNIFormity AND EQUALITY IN STATE TAXATION (1959).

38 See Dunham, $A$ Legal and Economic Basis for City Planning, 58 Colum. I. REv. 650 (1958).

39 Sometimes the rezoning itself is knocked out by the courts. See, e.g., Sinclair Pipe Line Co. v. Village of Richton Park, 19 I11. 2d 370, 167 N.E.2d 406 (1960). 
nobody has suggested it, there is no zoning enabling legislation anywhere in the country permitting such a thing.

The point is stressed because we believe that this lack is in great measure responsible for the so-called "development rights acquisition" program currently urged as a suitable device for preserving open space. Most advocates of open-space preservation concede that the land-use controls needed to accomplish its purposes will in most cases step beyond regulation into the realm of "taking." The absence of legislation enabling zoning subject to compensation for resultant "takings" has seriously restricted the range of ideas available for the solution of open-space problems.

It is not that the idea of paying for certain regulations is inconceivable or unconstitutional. In fact, prior to Village of Euclid $v$. Ambler Realty Co., ${ }^{40}$ zoning was commonly sought through eminent domain. ${ }^{41}$ A zoning ordinance in Kansas City, Missouri, ${ }^{42}$ and an enabling act in Minnesota ${ }^{43}$ - leftovers from a pre-Euclidian period and still on the books-combine zoning and eminent domain. They were not very successful largely because they depended on cross-compensation by private owners in the area, a system which created serious obstacles to changes and amendments. ${ }^{44}$ In any case, the pre-Euclidian period, when combinations of zoning and eminent domain were not unknown, seems to have been relegated to oblivion. ${ }^{45}$

40272 U.S. 365 (1926).

41 See Note, Constitutionality of Zoning Laws, 72 U. PA. L. REv. 421 (1924).

42 Kansas City, Mo., Ordinance 39946.

43 Minn. Stat. Ann. § 462.12 (1945),

44 See Burger v. City of St. Paul, 241 Minn. 285, 64 N.W.2d 73 (1954) ; State ex rel. Twin City Bldg. \& Inv. Co. v. Houghton, 144 Minn. 1, 176 N.W. 159 (1920); Kansas City v. Liebi, 298 Mo. 569, 252 S.W. 404 (1923). See generally Anderson, Zoning in Minnesota; Eminent Domain vs. Police Power, 16 NAT'L MUNIC. REv. 624 (1927).

45 Since our text was written, Professor Mandelker has published an interesting study in which he suggests that a combination of zoning and compensation, patterned after the English system, should be considered. Mandelker, Notes From the English: Compensation in Town and Contrtry Planning, 49 CALIF. L. REv. 699, 736-41 (1961). The English system, however, started with a "global" condemnation of all "development rights" in England as of the "appointed day"-July 1, 1948. Each owner was then required, within a limited period, to establish a claim to compensation representing the loss in value to his land as of the "appointed day." Town and Country Planning Act, 1947, 10 \& 11 Geo. 6, c. 61, $\S 12,58,60,61$. By a 1954 revision of the original act, the established claims were attached to and made to "run with the land" as a "claim holding." Town and Country Planning Act, 1954, 2 \& 3 Eliz. 2, c. $72, \S 2$. An owner whose request to develop is denied now has two remedies: He may force the authorities to condemn if he can show that his property "has become incapable of reasonably beneficial use in its existing state," Town and Country Planning Act, $1947,10 \& 11$ Geo. 6 , c. $61, \S 19$, or he may claim compensation, not to exceed, however, the amount of the "claim holding" attached to the land, Town and Country Planning Act, 1954, 2 \& 3 Eliz. 2, c. 72, §§ 17, 19, 25. Certain uses requested by the owner and denied by the authority are excluded from compensation. Town and Country Planning Act, 1954, 2 \& 3 Eliz. 2, c. 72, \$20. The line drawn between compensable and noncompensable denials of permission to develop is roughly the line drawn in this country between regulation and "taking." On p. 200 infra, 
If the solution of regulating and paying for the "taking" resulting therefrom does not suggest itself, then the only remaining solution is outright acquisition of "development rights," "scenic easements," and other "interests less than a fee." Typical of this approach are recent enabling acts in California, Maryland, New York, and New Jersey. While this legislation differs from state to state in its scope and purpose, all the acts have a provision enabling acquisition of "the fee or any lesser interest or right in real property." 46 The Maryland and New York acts add the words "development right, easement, covenant or any other contractual right necessary to achieve this end." ${ }_{47} \mathrm{New}$ Jersey adds the words "or right consisting, in whole or in part, of a restriction on the use of land by others including owners of other interests therein; such interest or right sometimes known as a 'conservation easement." " 48

These references to "lesser interests," "development rights," "covenants," "restrictions," and "conservation easements" are all designed to confirm a power which was not clearly granted before. The acts in California, Maryland, and New York authorize only consensual acquisition of such interests for the open-space purposes variously defined therein. But the New Jersey Green Acres Act provides for acquisition by condemnation. ${ }^{40}$ An effective open-space program of the development rights type can be carried out only if the power to acquire includes the power to condemn. The effects of openspace programs on the social and economic life of urban and suburban communities are far too serious to allow them to be exposed to haphazard implementation through consensual arrangements with willing property owners. Thus the California, Maryland, and New York acts may have only limited significance in the future. The New Jersey program, resting as it does on a power to condemn, embodies the most effective development rights approach. Even so, this approach suffers from a number of drawbacks.

\section{Lack of Flexibility}

One serious drawback in the development rights approach lies in the difficulty of defining what is being "taken." Obviously, a con-

we suggest that such a distinction introduces administrative complexities which outweigh any benefit to be obtained from it. A system of regulation and compensation which gives an owner a limited time to establish a "claim holding," which looks for its "compensable event" to the time when the owner requests permission to develop, and which draws elaborate distinctions between compensable and noncompensable denials, would appear to be too complex for the American scene.

46 E.g., CAL. Gov't Code $\S 6950$. (Emphasis added.)

47 Md. Ann. Code art. 66(c), §357(A) (Supp. 1960) ; N.Y. Munic. LAw $\$ 247$.

48 Green Acres Land Acquisition Act, N.J. Sess. Laws 1961, ch. 45, $\$ 12(\mathrm{~b})$.

49 Green Acres Land Acquisition Act, N.J. Sess. Laws 1961, ch. 45, §6. 
demnation petition cannot define the interest taken as simply "development rights." "Development rights," "scenic easements," and other "interests less than a fee" do not possess a clearly defined character in property law. In Pontiac Improvement Co.v. Board of Commissioners, ${ }^{50}$ a property owner challenged the right of the commissioners of the Cleveland Metropolitan Park District to condemn interests which were described in the petition as rights "to regulate and control all planting and floral decoration [and] . . . grading and filling . . . to prevent the erection or maintenance of any building, structure, fence or wall of any kind . . . ", and to prevent other described acts which might interfere with the amenities of an adjacent park. The commissioners sought to sustain their action under a statutory provision giving them the right to acquire and "protect" parks, parkways, and forest reservations, and in aid thereof to condemn "either the fee or any lesser interest." The court sustained the owner's challenge partly on the then prevailing view of what constitutes "public use," but mainly on the ground that:

In this case the rights and privileges which are sought to be secured are not certain, and their exercise by the board would be entirely indefinite. The right to regulate and control, the right to prevent certain things, such as the erection of fences, walls, structures, etc., when conferred upon the park board, is not of such a character as to inform the owner of the property as to what has been taken away from him or what uses it would be safe for him to make of his property in the future. ${ }^{51}$

It does not solve the problem simply to call what is being "taken" an "easement." In fact, even calling the interest an easement creates problems. At common law, there is some reluctance to recognize "new species of incorporeal hereditaments." 52 In England, for example, the "scenic easement deed" used by the California State Park Commission ${ }^{53}$ would probably be rejected as creating an easement. ${ }^{54}$ In this country there is no such great reluctance to recognize as easements

50104 Ohio St. 447, 135 N.E. 635 (1922).

$51 \mathrm{Id}$. at $463,135 \mathrm{~N} . \mathrm{E}$, at 640 , distinguishing Attorney General v. Williams, 174 Mass. 476, 55 N.E. 77 (1899), which upheld condemnation of air rights restricting height of buildings, on the ground that the interest there taken was definite and precise and the damages could easily be ascertained.

52 Hill v. Tupper, 2 Hurl. \& C. 121, 127, 159 Eng. Rep. 51, 53 (Ex. 1863).

53 Under which, for example, the grantor is prevented from making any use of his property "which, in the opinion and judgment of the said State Park Commission, will or does materially alter the landscape or other attractive scenic features of said land ...."The form of the deed is set forth in Wriyte, Securing Open Space FOR URBan AMERTCA: Conservation Easements app. C, at 60 (Urban Land Inst. Tech. Bull. No. 36, 1959).

64 See In re Ellenborough Park, [1956] 1 Ch. 131, 175-87 (dictum). 
"new species" of interests. ${ }^{55}$ However, the type of interest needed to accomplish open-space preservation is so unlike any easement and so like most restrictive covenants that one can expect the courts to treat them as covenants. It should be noted that the New Jersey Green Acres Act refers to the interest as "a restriction on the use of land . . . sometimes known as a 'conservation easement." "56 The point of all this is that there are strong indications in the law of restrictive covenants that flexible restrictions, depending for their definition on the exercise of somebody's discretion, will not be enforced by the courts unless there is a definite community scheme applicable to a described area which can supply a standard against which the exercise of discretion involved can be measured. ${ }^{57}$ Thus, if the development rights taken by condemnation are as vaguely defined as the restrictions of the scenic easement deed used by the California State Park Commission, subsequent enforcement of the restrictions will be extremely diffcult ${ }^{58}$-if not impossible - except in cases where the prohibitions of the restrictions are clear and unequivocal. Hence the development rights approach is hardly an ideal medium for introducing planning flexibility into the program for preserving large open-space areas of the type we suggest may be needed. (1942).

55 See Conard, An Analysis of Licenses in Land, 42 CoLum. L. REv. 809, 825-27

56 Green Acres Land Acquisition Act, N.J. Sess. Laws 1961, ch. 45, §12(b).

57 E.g., Hanula v. Hacienda Homes, Inc., 34 Cal. 2d 442, 211 P.2d 302 (1949) (dictum); Alliegro v. Home Owners of Englewood Hills, Inc., 122 A.2d 910 (Del. Ch. 1956) (dictum) ; Parsons v. Duryea, 261 Mass. 314, 158 N.E. 761 (1927) (dictum); Harmon v. Burow, $263 \mathrm{~Pa} .188,106$ Atl. 310 (1919) (dictum). If they are classified as covenants, enforcement of the rights held by the government authority upon condemnation of "development rights" may face the further objection that covenants affecting land cannot be enforced either at law or in equity against successors in interest to the burdened property unless the person seeking enforcement holds land which was intended to be benefited by the covenant-in short, that the burden of covenants in gross does not run with the land. While this doctrine has some merit in denying protection to mere holdout interests, its application to a government authority, representing as it does the property owners within its territorial boundaries, would seem absurd. Nevertheless, it has been applied to such cases. Hall v. Risley, 188 Ore. 69, 213 P.2d 818 (1950); London County Council v. Allen, [1914] 3 K.B. 642. The argument that it should not be applied to governmental bodies is readily found by analogy to property owners' association cases. See Merrionette Manor Homes Improvement Âss'n v. Heda, 11 Ill. App. 2d 186, 136 N.E.2d 556 (1956); Neponsit Property Owners' Ass'n v. Emigrant Indus. Sav. Bank, 278 N.Y. 248, 15 N.E.2d 793 (1938). In the case of enforcement at law, the courts also seem prepared to abandon the added requirement that there be privity of succession between the original covenantor and covenantee. See Nicholson v. 300 Broadway Realty Corp., 7 N.Y.2d 240, 164 N.E.2d 832 (1959). Whether Massachusetts is ready to abandon its unique position, requiring privity of estate, Morse v. Aldrich, 36 Mass. (19 Pick.) 449 (1837), remains to be seen.

58 See S. Rep. No. 433, 87th Cong., 1st Sess. 3 (1961): "Difficulties have. . . been encountered in connection with the scenic easements which were acquired by the States and conveyed to the National Park Service for the parkways. . . Experience has demonstrated many difficulties of administration, and a lack of effectiveness of these easements." 


\section{Cost Disadvantages}

Under the development rights approach, the community is forced to pay, at once, for all the development value existing in the area chosen for open-space preservation. If the area has considerable development value, the cost could be prohibitive. ${ }^{59}$ Normally, development value is realized by the owner-particularly the owner of land suitable for open-space preservation-through sale to a developer. The development rights approach forces the community to anticipate such realization, often, perhaps by many years. In short, the community pays now for a value the owner himself is not prepared to realize now. On the other hand, the community dare not await the owner's decision to develop, because this will result in mounting costs as more development value settles in the area. The condemnation of development rights may draw attention to the development potential of an area, lead to overstatement of that potential by each individual owner, and thus tend to inflate the actual development value settled in the area as a whole. This phenomenon has been well documented in the report of the Uthwatt Committee ${ }^{60}$ which led to the English Town and Country Planning Act of 1947.

\section{Unfairness to Owners or Community}

If development rights are condemned in an area with little or no development value, theoretically the measure of damages should be zero or close to it. But this result seems unfair. True, if the government condemned the fee in such an area, it would pay nothing for nonexistent development value. For example, if a tract of land used for farming is worth $\$ 20,000$, and farming is its "best and highest use," the condemning authority must pay $\$ 20,000$ for the fee. It pays nothing for "development value" because none has settled in the area. If the government condemns only the development rights, theoretically it should pay nothing. Yet there is suspicion that this theoretical result will be belied by actual awards. This derives, it is believed, from the fact that in taking the development rights, the condemning authority does nothing to guarantee the $\$ 20,000$ value existing at the

59 William H. Whyte, Jr., disputes this conclusion, citing Wisconsin's experience with scenic easements along state highways and showing that easement cost per acre was approximately one-quarter of the fee cost on one project, approximately onehalf on another. WHYтE, op. cit. stipra note 53, at 31-32. It is misleading to present a comparison between easement cost and fee cost as "cost per acre." The fact is that these were costs "per acre" confined to a strip along a highway whose maximum width was 350 feet from the center line. (There is no indication of the width of the highway.) The figure we want is the one obtained when development rights are condemned on whole properties.

60 Expert Committee on Compensation and Betterment, Report, CMr. No. 6386, at $15-16$ (1942). 
time of condemnation. Nobody can be sure that the value will in fact be realized by the owner when, sometime in the future, he comes to sell his property. By leaving room for wild conjectures, this uncertainty is likely to result in large awards to the owner to take care of a real or imagined future inability to sell at the present market value.

\section{Public Acquisition and Resale or Leaseback}

The development rights approach, used on any large scale, puts a great deal of property in government hands; this may suggest a further, practical difficulty with it. For better or worse, most Americans would probably react strongly to any proposal designed to put government in the real estate business on an extensive scale. For the same reason we think there would be strong opposition to any serious proposal that some sort of ad hoc governmental unit be created to acquire large tracts of undeveloped land essentially allocated for private occupancy and sell or lease these lands back to the original owners, subject to restrictions designed to secure open-space objectives. $^{61}$ In both situations a large initial outlay of capital would be

61 This kind of scheme has been proposed in Clawson, Suburban Development Districts-A Proposal for Better Urban Growth, $26 \mathrm{~J}$. Ass. Inst. of PLANNERS 69 (1960). The tax consequences of condemnation and leaseback suggest additional problems. As a device for controlling land use, it is a mistake to suppose that condemnation and leaseback will automatically secure to every owner in the area, whether or not he be engaged in business and in need of financing, the tax and financial benefits associated with voluntary sales and leasebacks. Voluntary sales and leasebacks are a financing device employed mainly by corporate enterprises in order to secure the following, sometimes dubious, advantages: (1) Additional capital in an amount equal to the full fair value of the property may be obtained without showing a concomitant liability on the balance sheet. Restrictive conditions attending other forms of borrowing may be avoided. The rental payments, however, generally represent full amortization of the "purchase price" plus interest at rates which are slightly higher than those prevailing for other forms of borrowing. Notwithstanding an option to renew, at the end of the initial period of the lease the fee value of the property to the vendor is effectively exhausted. Furthermore, if the property is essential to the business enterprise, future borrowing potential will not be significantly conserved. (2) If land forms a substantial part of the value of the property, tax-deductible rental payments enable the enterprise, in effect, to depreciate the land. Where, however, the property has a low basis in the hands of the vendor, the advantages of rental deductions must be compared with the capital gain recognized on the sale. Under INT. REv. CODE of 1954, $\$ 1031$ (a), no gain or loss is recognized "if property held for productive use in trade or business or for investment . . is exchanged for property of a like kind." The regulations state that an exchange of "a leasehold of a fee with 30 years or more to run for real estate" is an exchange of "like kind" properties. Treas. Reg. $\$ 1.1031$ (a)-1(c) (2) (1956). However, upon an exchange of "like kind" properties gain is recognized to the extent of cash or "boot" received, INT. REv. CODE of 1954, $\S 1031$ (b), while loss is not recognized even if cash or "boot" is received, INT. REv. CODE of $1954, \S 1031$ (c). The effect of these provisions on recognition of loss in the sale and 30-year leaseback situation is still unclear. Compare Century Elec. Co. v. Commissioner, 192 F.2d 155 (8th Cir. 1951), cert. denied, 342 U.S. 954 (1952), with Jordan Marsh Co. v. Commissioner, 269 F.2d 453 (2d Cir. 1959). The Bureau has announced that it will not follow Jordan Marsh. Rev. Rul. 60-43, 1960-1 Cum. BuLl. 687.

Tax treatment of involuntary conversion (condemnation) of "real property . . . held for productive use in trade or business or for investment" has been brought in 
required, although, of course, the debt could eventually be amortized through rentals or resale proceeds. And in both situations, as we shall see, there may be difficult "public purpose" constitutional objections. If resale is used, the difficulty of framing deed restrictions would pose problems analogous to those already suggested in connection with development rights. And condemnation of property followed by long-term leasebacks might put many homeowners in a tenurial relationship to the government-a result which is pretty drastic, particularly if other, more palatable alternatives are available. Thus we believe the device of condemnation and resale or leaseback, while useful for limited purposes, is probably not feasible as a method to secure more ambitious goals.

\section{E. Summary of Deficiencies in Existing Techniques}

Our analysis of existing techniques under the police power and of development rights and property acquisition schemes suggests a number of deficiencies. Three are basic. First, police power techniques must surmount the objection that they involve a "taking" of the property. In the context of a substantial moratorium on development necessary to preserve open space, they may contain the seeds of their own disruption (such as the provision concerning "reasonable return"

line with voluntary exchanges by an addition to $\S 1033$ providing that involuntary conversion of such property into or reinvestment of the condemnation proceeds in "property of like kind" shall be treated as a conversion into or reinvestment in "property similar or related in service or use." 72 Stat. 1641 (1958), adding INT. REv. CODE oF 1954, $\S 1033(\mathrm{~g})$ (effective as to conversions occurring after December 31,1957$)$. Whether this affects treatment of loss as well as gain remains to be seen.

In any case, even if the condemnation and leaseback scheme for the control of land use is confined to business, trade, or investment properties, it seems obvious that the tax and financial benefits associated with voluntary sales and leasebacks will not necessarily be secured to the owner. We assume that current proposals for condemnation and leaseback envisage payment of compensation substantially equal to the value of the fee, with a leaseback at rentals representing amortization of principal plus interest on bonds issued to meet the payment of compensation. Clearly, then, gain will be recognizable, even as to business properties, to the extent of the compensation paid. The tax liability for some condemnees may be greatly in excess of any tax benefit derived from the deductibility of rental payments. Reinvestment of the proceeds in "like kind" property may not be desirable. Moreover, the business may not be in need of this type of financing or of any financing.

With respect to tax consequences, the scheme of condemnation and leaseback breaks down completely when applied to properties whose owners are not entitled to rental deductions under INT. REv. CODE of 1954, $\$ 162$ (a) (3). An owner of residential property, condemned and leased back to him, would find it rather difficult to reinvest the proceeds of condemnation in "property similar or related in service or use."

The tax consequences of a "development rights" acquisition scheme or of the scheme proposed in this article are less troublesome. Compensation paid in respect of a governmental curtailment in use of property goes to reduce the basis in such property and is taxable only to the extent that it exceeds such basis. Inaja Land Co., 9 T.C. 727 (1947); Rev. Rul. 59-121, 1959-1 Cum. Bulz. 212; Rev. Rul. 54-575, 1954-2 Cum. Bulz. 145 (air rights); I.T. 2621, XI-1 Cum. Bull. 67 (1932). 
in the official map laws) and must, in any case, be exposed to constant encroachment through attack on their constitutionality as applied. The very possibility of such attack could itself inhibit proper planning of open space. Following each successful attack on the regulation as applied to particular property, the plan must either be abandoned as to such property or reinstated through condemnation at values inflated by the passage of time and the unspoiled character of surrounding (restricted) property. Second, the development rights acquisition approach frankly requires that the interests needed to accomplish openspace objectives be "taken" and immediately paid for by the community. This approach, however, calls for a present expenditure to compensate for values which the owners themselves may not have intended to realize for some time. Under this approach, too, the rights taken must be defined with minute particularity-sacrificing planning flexibility-or left vague-creating problems of enforcement. Third, there are serious political and related objections to any scheme of landuse controls which puts government in the real estate business permanently and on a grand scale.

Despite this detailed criticism, we do not suggest that open-space legislation of the type already enacted or proposed in various states is fruitless. Quite the contrary. Not only has enactment of this legislation helped to "educate," but these tools may be vital or best suited to the accomplishment of some open-space objectives such as reservation of limited areas to protect parks or future park sites. We submit, however, that these laws are not well suited to achieve bolder programs-objectives of the sort we have posited in this Article.

\section{A New APPROACH}

\section{A. The Legal Device}

What is needed for the successful accomplishment of an open-space program is a scheme that does not depend on the impermanent strength of noncompensable regulation or on the acquisition of inflexible "property interests," that prevents overcompensation and concentration of costs, and that furnishes security to the owner and encourages upkeep of the properties in the area. The makings of such a scheme are presented in the legislative proposal appended to this Article. It takes the following form: When the area to be preserved or developed for open-space purposes has been chosen, through procedures and within a governmental structure which best assure maximum benefit to the community, the properties in the area are valued. The valuation is based on the same principles and is accomplished under the same procedures as is the valuation of property for purposes of "just compensa- 
tion" in condemnation (Sections 300(a) and 400-06). The values thus established for each property in the area are guaranteed to the owner by the government authority (Section 300 (a)). The aggregate of these guarantees for the whole area is equal to the compensation which would be payable if the whole area were condemned in fee on the date when the open-space program goes into effect. The fee, of course, is not condemned. Instead, detailed regulations controlling the uses of the property for open-space purposes are imposed against the guarantees (Section 204).

To the extent that such controls depress the value of the land for uses actually being made of it at the time they are imposed, the owner is permitted to draw on his guarantee for damages (Section $302(a))$. To the extent that such controls depress the value of the property for other than existing uses-depress or eliminate development worth-the owner may draw on his guarantee through an administratively supervised public sale of his property (Section 303(b)) in an amount by which the guarantee allocable to his interest exceeds the proceeds received by him from the sale. The guarantee established for any property in the area is reduced by each payment of damages or compensation (Section 300(d)(2)). Thus the damages and compensation payable by the community cannot exceed the guarantee established for each tract. What this means, in effect, is that development values not existing on the date when open-space controls are imposed are not compensated.

Since the owner would draw on his guarantee for loss to existing use value as soon as the controls were imposed, his compensation at the public sale would represent loss of development value existing when the controls were imposed. The requirement that the owner be prepared to sell his interest before receiving compensation for such loss should strike a fair balance between the interests of the community and those of the owner.

As was pointed out in our criticism of the development rights approach, it is unfair to require the community to pay compensation, based on the usual conflicting testimony, for values, real or imaginary, which the owner himself has no intention to realize. Under our proposal, the owner's compensation for loss of development value is deferred to the point in time when he would normally have realized that value, and it is then computed not on the basis of conflicting testimony but on the basis of the actual market for regulated property. The requirement of an administratively controlled public sale is intended to protect the community against fraudulent schemes designed to milk the community on its guarantee. 
In return for these restrictions, the owner receives the benefit of a governmental guarantee of the value of his property existing on the date when the open-space controls were imposed. The guarantee lasts as long as the controls continue and is good not only against loss in value caused by regulation but against general depressions in real estate values. When drawn upon, the guarantee is adjusted for changes in the value of the dollar (Section 300(d)(1)).

\section{B. Compensable and Noncompensable Regulation}

No attempt is made in the proposed Act to separate compensable from noncompensable regulation. Were the scheme of the Act to draw such a distinction, it would pose grave administrative and conceptual problems. It would require that the regulations be classified in two categories-those characterized as compensable and those characterized as noncompensable-and that the loss established under Section 302, relating to damages, or under Section 303, relating to compensation, be attributed to or apportioned between the two categoriesan impossible task.

It seems well established that the condemner may rely upon existing zoning when the property comes to be valued for purposes of condemnation. ${ }^{62}$ But a number of cases hold that the condemner may not rely on zoning which, while otherwise valid, was adopted with a view to depressing values for condemnation. ${ }^{83}$ An owner's argument that it is inequitable for a government body deliberately to zone to the maximum extent of its regulatory power in order to reduce compensation payable on the exercise of its power of eminent domain is likely to receive a sympathetic hearing from the courts. Were the act to draw the distinction supposed, this argument would seem to be available to owners in the open-space area. Given these administrative problems and this possible source of litigation, the savings which could be secured by drawing such a distinction would seem to be negligible.

\section{Expected Benefits of the Scheme}

Hopefully, the eclectic approach taken by the proposed Act will have several significant advantages over other devices which have been employed to achieve partially some of the goals of comprehensive openspace planning. Broadly stated, the Act will be less costly to the community than other schemes, it will avoid concentration of costs during the initial period of regulation, and it will foster more rational planning.

624 Nichols, Eminent Domain \$12.322 (3d ed. 1951).

63 See cases cited note 34 supra. 
Since the valuation for purposes of establishing the guarantee is a valuation of the whole fee, it should escape the pressures for overstatement of development value which attend valuation of development rights. In addition, intervening increases in market values at the regulated level will inure to the benefit of the community, thus further insuring that the cost of regulation will be lower than the acquisition of development rights. For, as market values rise to equal the guarantees, the community pays less and less; when the values equal or exceed the guarantees no further payments need be made. Except in its provision for public sale (Section 303(b)), the Act itself lends encouragement to an optimum market at the regulated level by extending the guarantee to purchasers, penalizing low offers at public sales by limiting the purchaser's guarantee to the price paid at such sale (Section 303(b)), and allowing claims for damages upon amendment to the regulations (Section 302(b)).

In view of these and other effects attributable particularly to the guarantee, ${ }^{64}$ it is not expected that open-space regulation will result in mass exodus from the area. Therefore, the cost of paying for loss of development value caused by the controls will be spread over a period of time rather than concentrated in the year in which the controls are imposed.

The amount of development value existing in an area is probably related to its accessibility from the nearest urban center. The more accessible the area, the more attractive it should be to those who are willing to pay high prices for the assurance-provided by the Act-of the natural or "unspoiled" condition of the land. It is expected that these forces will assure that the community outlay for keeping an area open will not greatly differ between areas which possess a high level of development value and areas which do not. The effect of thus levelling the cost of keeping various land areas open should be to encourage planning of open spaces without regard to the amount of development value existing in the area. Another encouragement to more rational planning is the element of flexibility introduced by the guarantee of original value. An amendment to the regulations simply falls within the general scheme of the Act. To the extent that the amendment depresses the regulated value of the property existing before the amendment, the owner may draw on the guarantee in that amount (Section 302(b)(1)). To the extent that the amendment

64 A significant indirect benefit of the scheme is the encouragement which the guarantee will give to institutional lenders. In effect, a mortgage on open-space property would seem to be government insured at $100 \%$ of the guarantee. This should result in easy credit and, hopefully, lower interest rates on private improvement loans. Banking laws may be amended to obtain the maximum benefit of this factor for the conservation of open-space areas. 
further depresses or eliminates development value, compensation is postponed until public sale (Section 303(b)).

\section{The Public Purpose Problem}

Our proposal for securing metropolitan open-space areas contemplates use of police power regulations, appropriation of public funds to guarantee property values in regulated areas, and, in certain circumstances, forced alienation of property-in effect, condemnation. The objective is to create metropolitan "green areas" in order to advance not only such traditional governmental objectives as recreation and conservation but some more novel objectives: to prevent undue economic burdens arising from use of land unsuited for intensive development; to reserve land for uses needed in the future; to preserve aesthetic amenities, scenic areas, and other, similar, intangible values. These may be traditional goals of planning, but they are goals which state and local governments in this country have seldom attempted to implement on a broad scale. Should the courts sustain these objectives as a legitimate "public purpose?" ${ }^{65}$

It is familiar history that in earlier times courts developed from constitutional language (or from some source such as "higher law") the "public purpose" limitations on government's power to regulate or spend and the analogous limitation that condemnation must be for "public use." ${ }^{66}$ The nineteenth century courts were strict: legislative declarations to the effect that a project served a "public purpose" were sometimes swept aside with little deference; the term "public use" was equated to a limitation requiring actual "use by the public," and projects for the promotion of a more aesthetic community or for relief of depressed areas were sometimes said to be beyond the constitutional

65 We put aside the temptation to discuss in detail whether and to what extent the "public use" limitation on eminent domain, the "public purpose" limitation on expenditures of public funds or credit, and the "general welfare" limitation on the police power may differ from one another. See, e.g., 1 CoOLEY, TAXATION \$87 (4th ed. 1924); McAllister, Public Purpose in Taxation (pts. 1-2), 18 CaLIF. L. Rev. 137, 241 (1929); McDougal \& Mueller, Public Purpose in Public Housing: An Anachronism Reburied, 52 Y ALE L.J. 42 (1942); Nichols, The Meaning of Public Use in the Law of Eminent Domain, 20 B.U.L. REv. 615 (1940); Note, 108 U. PA. L. REv. 95 (1959). For reasons brought out in the text, we think that eminent domain cases sometimes raise peculiarly difficult public purpose questions since they involve forcible taking or transfer of property-and sometimes considerable discretion in determining whose property-to effectuate the goals of legislation. But even in these cases, as the text will attempt to show, there are some issues involved in the general public purpose determination which ought to be treated no differently whether the case involves regulation, expenditure, or eminent domain.

66 See sources cited note 65 supra. See also Loan Ass'n v. Topeka, 87 U.S. (20 Wall.) 655 (1874) (first important statement of the doctrine by the Supreme Court); People ex rel. Detroit \& H.R.R. v. Salem, 20 Mich. 452 (1870) (formulation by Cooley, J.); Bloodgood v. Mohawk \& H.R.R., 18 Wend. 9, 60 (N.Y. C.t. for Correction of Er. 1837) (opinion of Senator Tracy); Sharpless v. Philadelphia, $21 \mathrm{~Pa} .147$ (1853) (formulation by Black, C.J.). 
power of state or municipal governments. ${ }^{67}$ But "public purpose" is a constitutional limitation which peculiarly changes with changing concepts of public responsibility; ${ }^{68}$ and there has been a reappraisal and retreat as governmental activity has expanded into such fields as public assistance, ${ }^{69}$ housing, ${ }^{70}$ transportation, ${ }^{71}$ recreation, ${ }^{72}$ entertainment, ${ }^{73}$ development of the arts, ${ }^{74}$ slum clearance, ${ }^{75}$ rehabilitation of depressed urban areas, ${ }^{76}$ and plant construction to promote industrial development. ${ }^{77}$ Indeed the Supreme Court has apparently all but renounced the public purpose doctrine in construing the federal constitution. ${ }^{78}$ But all this has not, as some have argued, ${ }^{79}$ marked the demise of the public purpose doctrine. Whether or not it is an "anachronism," 80 we must reckon with it because it still exists and has been wielded with some vitality by some courts in some cases involving novel landuse controls. ${ }^{81}$

Some generalizations may be in order before turning to our particular problem. The public purpose doctrine appears to encompass a number of different but related propositions; litigation testing the constitutionality of particular legislation, such as a law authorizing local governments to acquire and resell property in order to promote

67 See, e.g., Pennsylvania Mut. Life Ins. Co. v. Philadelphia, $242 \mathrm{~Pa} .47,53,88$ Atl. 904, 908 (1913). The court quoted the words of Judge Cooley: "It may be for the public benefit that .. all unsightly places [be] beautified . . . but the common law has never sanctioned an appropriation of property based on these considerations alone . . ." Cooley, Constitutional Linitations 768 (7th ed. 1903).

${ }^{68}$ See, e.g., People ex rel. Adamowski v. Chicago R.R. Terminal Authority, 14 IIl. 2d 230, 236, 151 N.E.2d 311, 314 (1958) ; Dornan v. Philadelphia Housing Ass'n, 331 Pa. 209, 221, 200 A.2d 834, 840 (1938); cf. Green v. Frazier, 253 U.S. 233 (1920). ${ }^{69}$ Cf. Carmichael v. Southern Coal Co., 301 U.S. 495 (1937).

70 See, e.g., Dornan v. Philadelphia Housing Ass'n, 331 Pa. 209, 200 A.2d 834 (1938).

71 Cf. McSorley v. Fitzgerald, 359 Pa. 264, 59 A.2d 142 (1948) (parking authority). A discussion of this aspect of changing governmental and court attitudes may be found in Note, 108 U. PA. L. REv. 95, 96-98 (1959).

72 See State v. Daytona Racing \& Recreational Facilities Dist., 89 So. 2d 34 (Fla. 1956). (1958).

${ }^{73}$ See City of Los Angeles v. Superior Court, 51 Cal. 2d 423, 333 P.2d 745

74 See Bernstein v. Pittsburgh, 366 Pa. 200, 207-09, 77 A.2d 452, 455-56 (1951);

cf. Thomas v. Daughters of Utah Pioneers, 114, Utah 108, 197 P.2d 477 (1948).

75 See People ex rel. Gutknecht v. Chicago, 414 I11. 600, 111 N.E.2d 626 (1953).

See generally McDougal \& Mueller, supra note 65 .

${ }^{76}$ See, e.g., Oliver v. Clairton, $374 \mathrm{~Pa}$. 333, 98 A.2d 47 (1953); Belovsky v.

Redevelopment Authority, $357 \mathrm{~Pa} .329,54$ A.2d 277 (1947).

77 See, e.g., Wayland v. Snapp, 334 S.W.2d 633 (Ark. 1960); McConnell v.

City of Lebanon, 203 Tenn. 498, 314 S.W.2d 12 (1958); cf. Oliver v. Clairton, supra note 76.

78 See Berman v. Parker, 348 U.S. 26 (1954); United States ex rel. TVA v. Welch, 327 U.S. 546 (1946).

${ }^{79}$ See Comment, The Public Use Limitation on Eminent Domain: An Advance Requiem, 58 YALE L.J. 599 (1949).

80 See McDougal \& Mueller, supra note 65.

81 See, e.g., Hogue v. Port of Seattle, 54 Wash. 2d 799, 341 P.2d 171 (1959). 
its development in harmony with new community planning goals, may involve any one of a number of contentions. The argument may be that the ultimate goals which the legislation seeks to achieve are beyond the purview of government, ${ }^{82}$ or that there is no demonstrable, factual necessity justifying the legislation. ${ }^{83}$ It may be argued that the means used to promote the objective are illegal, for example, because one person's land is seized for transfer to some other private person. ${ }^{84}$ (This may be a significant defect if the ultimate objectives of the project might feasibly be achieved without disturbing ownership rights-at least by giving the original owner the option of staying on and keeping his property up to development standards.) Or it may be urged that the government has been put too much into the real estate business, ${ }^{85}$ or that the measure will supply great economic advantage to a few but only incidental benefit, if any, to larger segments of the community, ${ }^{86}$ that the legislation delegates too much discretion to administrative officials with the attendant risk of discriminations and favoritism, ${ }^{87}$ or that it lacks other basic procedural safeguards.

The precise scope of judicial review in these cases is not always made clear. ${ }^{88}$ But it would appear that some contentions are more susceptible to review than others. Legislative findings of the need for remedial action and conclusions that the stated ultimate goals of the legislation will advance the public welfare ought to stand-at least where these propositions have been spelled out with reasonable clarity and logic. A legislature's assertion that the method used to

82 See Schneider v. District of Columbia, 117 F. Supp. 705 (D.D.C. 1953), aff'd sub nom. Berman v. Parker, 348 U.S. 26 (1954); People ex rel. Gutknecht v. Chicago, 3 I11. $2 \mathrm{~d} 539,121$ N.E.2d 791 (1954).

83 See, e.g., Housing Authority v. Johnson, 209 Ga. 560, 74 S.E.2d 891 (1953); Opinion of the Justices, 332 Mass. 769, 782-83, 126 N.E.2d 795, 801-02 (1955); cf. Schenck v. Pittsburgh, 364 Pa. 31, 70 A.2d 612 (1950).

84 See, e.g., Schneider v. District of Columbia, 117 F. Supp. 705, 717 (D.D.C. 1953), aff'd sub nom. Berman v. Parker, 348 U.S. 26 (1954); Opinion of the Justices, supra note 83; Pennsylvania Mut. Life Ins. Co. v. Philadelphia, $242 \mathrm{~Pa}$. 47, 88 Atl. 904 (1913); Allydonn Realty Corp. v. Holyoke Housing Authority, 304 Mass. 288, 292, 23 N.E.2d 665, 667 (1939) (dictum). See also San Francisco v. Ross, 44 Cal. 2d 52, 279 P.2d 529 (1955).

85 See Opinion of the Justices, 332 Mass. 769, 781-84, 126 N.E.2d 795, 802-03 (1955) ; Hogue v. Port of Seattle, 54 Wash. 2d 799, 341 P.2d 171 (1959); cf.' Winger v. Aires, 371 Pa. 242, 247-48, 89 A.2d 521, 523-24 (1952) (dictum). (1959).

86 Compare Hogue v. Port of Seattle, 54 Wash. 2d 799, 827, 341 P.2d 171, 187

87 See, e.g., Hogue v. Port of Seattle, supra note 86; Belovsky v. Redevelopment Authority, 357 Pa. 329, 341-43, 54 A.2d 277, 283-84 (1947) (dissenting opinion); Note, 68 HARv. L. Rev. 1422, 1429 (1955) ; cf. San Francisco v. Ross, 44 Cal. 2d 52, 279 P.2d 529 (1955).

88 See Comment, The "Public Purpose" of Municipal Financing for Industrial Development, 70 YALE L.J. 788, 798-803 (1961). Compare the separate views of Black, Frankfurter, and Reed, JJ., in United States $e x$ rel. TVA v. Welch, 327 U.S. 546 (1946). 
secure these goals will be effective and that the method chosen is necessary should likewise be entitled to weight, insofar as the judgments here involve investigations and evaluations which legislative bodies, in theory, are best equipped to make. These broad issues, after all, can be resolved through the ballot box, and the courts may be on shaky ground when they try to delimit the responsibilities of government in a democratic society or when they frustrate attainment of valid welfare objectives by flatly declaring that the only feasible means of securing them are unconstitutional. But other "public purpose" contentions which cannot be reviewed so effectively by appeal to the electorate may be more susceptible of judicial review. While it may be undesirable for courts to condemn outright-on its face-a particular method of securing a desired and permissible result, it may be appropriate, where that method appears to involve possibilities of considerable hardship or special advantage to specific individuals-as where $A$ 's property is given to $B$-to examine the details of the legislation, such as the extent to which broad discretion is delegated, the standards which govern the scope of the legislation, the procedural requirements permitting both the community at large and directly affected citizens to be heard, and the extent to which the electorate has control, through elected officials, over decisions to undertake particular projects. Focusing on the same type of questions, judicial review of legislation as applied in particular cases may be appropriate; and perhaps in these respects the public purpose doctrine, for all its confusing clumsiness, is a desirable safeguard.

These considerations are sometimes, but certainly not always, reflected in the cases. In any event they may suggest some of the issues which should be analyzed in determining whether our proposal for metropolitan green areas and land reservation would be upheld, if challenged.

\section{A. Purposes of the Act}

The ultimate purposes of the proposal would seem to fall into four categories: (1) protection against excessive costs to the public resulting from failure to reserve land which will be needed later for public facilities or from intensive use of land in areas which cannot be economically served or equipped with necessary facilities; (2) protection or advancement of the economy of the metropolitan regionfor example, by preserving land needed for necessary industrial uses; (3) protection or advancement of aesthetic and related values; and (4) advancement of what seem to be traditional governmental re- 
sponsibilities ${ }^{59}$ in such fields as recreation, conservation, transportation, water resources development, and flood control.

In our draft proposal we have tried to spell out these objectives and to suggest the "factual" assumptions to which legislative attention should be directed in weighing the need for action and in "finding" that these are proper "public purposes." Moreover the proposed legislation goes further than may be usual in its requirements that the objectives of each project actually undertaken be clearly stated and the underlying factual necessity for the project be determined: the powers authorized in the Act can never be used unless the political subdivision through its elected governing body approves a detailed statement of the objectives of the project, embodying factual data showing its need.

In view of all this, we do not think the courts should deny, out of hand, that the legislation serves a public purpose. Moreover, some of the recent cases in the "redevelopment" and "industrial development" fields lend support to the conclusion that the kind of "aesthetic" and "economic" objectives we postulate are valid. In the now famous case of Berman v. Parker, ${ }^{90}$ the Supreme Court upheld a redevelopment project, one avowed purpose of which was to secure "a better balanced, attractive community." Justice Douglas' impressive dictum that it is within the police power to make a community beautiful as well as healthy ${ }^{91}$ has been widely quoted with approval by other courts. $^{92}$ Certainly aesthetic and related objectives, when coupled with other more tangible objectives-such as saving public costs, promoting employment, or enlarging public recreation opportunities-, ought to be permissible goals of local government today. While there is no unanimity among reported decisions on how tightly legislation can control land use in order to save money and improve the tax base, the courts have begun to recognize that the vast sums spent for planning to achieve these goals will amount to little if government is denied the tools to implement the plans. ${ }^{93}$ In Belovsky v. Redevelopment Authority, ${ }^{94}$ the Pennsylvania court upheld a statute authorizing condemnation of properties in "blighted" areas_ "blight" meaning, among other things, areas which were "inadequately planned" or put to

89 See, e.g., Carey v. United States, 143 F.2d 445, 449 (9th Cir. 1944); Bernstein v. Pittsburgh, 366 Pa. 200, 77 A.2d 452 (1951).

90348 U.S. 26 (1954).

$91 \mathrm{Id}$. at $32-33$.

92 See, e.g., Bilbar Constr. Co. v. Board of Adjustment, 393 Pa. 62, 73, 141 A.2d 851, 857 (1958).

93 See, e.g., Berman v. Parker, 348 U.S. 26, $33-36$ (1954) ; People ex rel. Gutknecht v. Chicago, 414 I11. 600, 111 N.E.2d 626 (1953); Bilbar Constr. Co. v. Board of Adjustment, supra note 92, at 73, 141 A.2d at 857 .

$94357 \mathrm{~Pa} .329,54$ A.2d 277 (1947). 
"economically or socially undesirable uses." Elimination of "blight," as thus broadly defined, was the "major purpose" of the Act, said the court, "and that purpose certainly falls within any conception of "public use,' for nothing can be more beneficial to the community . . . ." 95 Other cases, too, have upheld projects essentially concerned with rehabilitation of commercial areas to stimulate the economy, stressing the fact that an important and valid object of redevelopment is the replanning and improvement of areas which yield low tax returns and "consume an excessive proportion of [the city's] revenues because of extra services required ...." ${ }^{96}$ A number of courts have also upheld, as valid public purpose expenditures, legislation authorizing local governments to acquire-and in some cases to condemn-land to build industrial facilities and lease them to private concerns. ${ }^{97}$ While the means used to implement these projects may be most relevant in judging their validity, ${ }^{98}$ the courts have generally stated that the ultimate purpose of securing industry needed to "balance" the local economy and improve the labor market is, today, a valid purpose. Courts have also upheld condemnation of lands needed for future uses necessary for the community, ${ }^{99}$ and have recognized that-given proper enabling legislation-it is a proper use of the police power to employ zoning and subdivision controls to impede development and thus avoid the costly extension of services. ${ }^{100}$ All of these lines of authority support, we believe, the validity of the ultimate objectives which we have postulated in our proposal.

$95 \mathrm{Id}$. at $339,54 \mathrm{~A} .2 \mathrm{~d}$ at 282 .

96 Ibid. Cf., e.g., Redevelopment Agency v. Hayes, 122 Cal. App. 2d 777, 266 P.2d 105 (Dist. Ct. App. 1954); Gohld Realty Co. v. City of Hartford, 141 Conn. 135, 104 A.2d 210 (1954); People ex rel. Adamowski v. Chicago R.R. Terminal Authority, 14 III. 2d 230, 151 N.E.2d 311 (1959).

97 See cases cited note 77 supra; Comment, 70 YALE L.J. 789 (1961).

98 See McConnell v. City of Lebanon, 203 Tenn. 498, 314 S.W.2d 12 (1958); Note, 108 U. PA. L. Rev. 95 (1959) ; Comment, 70 YALE L.J. 789 (1961) (collecting and analyzing cases).

99 See Caslor Co. v. City of Miami, 62 So. $2 d$ 897, 902 (Fla.), cert. denied, 346 U.S. 821 (1953); Campbell v. Township Committee, 101 N.J.L. 461, 129 Atl. 757 (Sup. Ct. 1925). Compare, e.g., Town of West Hartford v. Talcoll, 138 Conn. 82, 82 A.2d 351 (1951) (all land "reasonably necessary" may be taken), with Grand Rapids Bd. of Educ. v. Baczewski, 340 Mich. 265, 65 N.W.2d 810 (1954)' (future school site not shown to be necessary).

100 See the analysis of zoning and subdivision cases in Smith, Municipal Economy and Land Use Restrictions, 20 LAW \& CONTEMP. ProB. 481 (1955); cf. Gruber v. Mayor \& Township Comm., 172 A.2d 47, 51-52 (N.J. Super. Ct. 1961). But cf. Midtown Properties, Inc. v. Township of Madison, 172 A.2d 40, 47 (N.J. Super. Ct. 1961). See also Newark Milk \& Cream Co. v. Township of Parsippany-Troy Hills, 47 N.J. Super. 306, 327-28, 135 A.2d 682, 694-95 (Super. Ct. 1957). Professor Paul Davidoff, of the Institute of Urban Affairs of the University of Pennsylvania, has written a valuable paper on "Conservation of Municipal Expenditures: A Valid Police Power Objective?" for one of the authors, which has been helpful not only here but in other respects in connection with analysis of the police power problems. 


\section{B. The Means Employed by the Act}

The means employed in our proposal should avoid, insofar as it is possible to avoid them, the "evils" which courts have sometimes singled out in "public purpose" cases. No owner is forcibly oustedexcept where property interests may in effect be taken for uses by the public. In other respects it is hoped that the proposal avoids features sometimes singled out and criticized by the courts. Though the proposal does involve detailed regulation of large areas of land, it does not-as do other open-space proposals-entail government ownership of vast property interests. Though the proposal does involve guarantees of value to owners of regulated land, and thus a pledge of public credit to private interests, this is a necessary quid pro quo for the extensive controls and risks imposed upon them. Nor are private owners given any special opportunity for financial gain by virtue of this provision. As is spelled out later, the proposal attempts to set out detailed planning standards designed to limit discretion and limit the exercise of powers granted to projects which are first carefully evaluated from the standpoint of whether they meet a public interest. It also calls for hearings at which the public may challenge required findings of fact showing conformity to the standards and other requirements of the Act. Decisions to undertake a project rest completely with the governing bodies of political subdivisions; no rulemaking power is delegated to nonelected officials; thus power is centered in men who can be called to account by the electorate.

Hopefully, all these factors, considered in the context of the ultimate objectives to be secured and the more drastic alternative means of accomplishing them, would lead to the conclusion that the legislative scheme we have proposed satisfies the public purpose doctrine.

\section{Planning Requirements and Intergovernmental.}

\section{COORDINATION}

"Open space," we have seen, is an amorphous term connoting a wide variety of planning objectives. We have hypothesized-without attempting to prove- that the most important need is for comprehensive, multipurpose open-space projects which will benefit entire metropolitan areas in a variety of ways. And we have attempted to fashion a legal device to enable that need to be met. There remain problems of determining what units of government should be empowered to act and pursuant to what standards. The same conditions which have impeded effective solution of other metropolitan problems may make this, too, a hard question. 
All levels of government-and different agencies operating at the same level-are engaging in activities which may influence the development of the metropolis or its parts. We need hardly pause to describe roles now assumed by federal, ${ }^{101}$ state, and local government, or to speculate on their impact. We know they are already myriad and significant. With reference to open space, one problem which confronts us is: which governmental units should exercise power to plan, aid, or implement open-space conservation measures?

There is at present a serious lack of comprehensive planning for land use in many metropolitan areas. Competing claims for the use of land may be championed by diverse agencies-both governmental and private-and land desired by one group for open-space purposes may also be desired by other groups for other uses; the "public interest" as conceived by one pressure group or one small government may not reflect the best interests of the larger region. Experience suggests that there have sometimes been abuses by small municipalities of the power to zone or to take land for parks ${ }^{102}$ or of the analogous (for these purposes) power to acquire sites for redevelopment projects. ${ }^{103}$ No matter where power is lodged, some standards and sense of priorities must still be formulated to guide those empowered to plan and secure open space.

One may expect misunderstanding or hostility as a reaction to proposals which envision broadened government ownership or control of land, for it may be one thing to reserve open space for immediate development of some traditional public facility, but it is quite another matter to reserve it-at public expense but without public possessionsimply to promote aesthetics and to control the forces of private development now and for the indefinite future. Notwithstanding precedent in the redevelopment field, this technique of land-use control may appear to many to be a radical departure.

Many people cherish the principle, whether or not it is illusory today, that power to control community development ought to be kept at the grassroots, the most local level; ${ }^{104}$ it may be argued that any similar power over land use ought to be treated in a similar way. Such suspicion may be especially strong in some of the very communities that are important for present purposes-those that now enjoy open spaces.

101 See Connery \& Leach, The Federal Government and Metropolitan AREAS (1960).

102 See Progress Dev. Corp. v. Mitchell, 286 F.2d 222 (7th Cir. 1961).

103 Cf. Sullivan, Administrative Procedure and the Advocatory Process in Urban Development, 45 CaLIF. I. REv. 134 (1957).

104 See Wood, Metropolis Against Itself (1959); Wood, Suburbia-Irs People aNd Their Politics (2d ed. 1958). 
Probably few political subdivisions could afford a large outlay to effect open-space objectives. ${ }^{105}$ Ways must be found not only to reduce costs to a minimum and to keep property on the tax rolls at the highest possible valuation, but also to spread costs over a broader base by supplying some state contributions, to take the best possible advantage of the federal grant-in-aid program, and to avoid dissipation of these resources on more parochial projects.

The draft Open Space Act tries to meet the problems discussed above by: (1) creating a regional unit of government to stimulate planning of open-space projects needed by the region as a whole, to receive state and federal grants-in-aid for open-space projects to be undertaken by political subdivisions in the area, and to carry out specified administrative functions; (2) treating existing political subdivisions-we suggest cities and counties in Pennsylvania-as the critical units of government by giving them ultimate authority to enact the regulations; (3) laying down certain general standards which shall govern decisions to allocate land for open-space purposes; (4) requiring that both the regional and the enacting local public body make findings that these standards will be met by each project; and (5) providing for procedures to permit aggrieved citizens and groups, under limited circumstances, to challenge land allocations for openspace purposes.

While it is desirable that all open-space projects be compatible with local, state, and regional "comprehensive plans," where they exist, it may be unwise to require a completed plan as a prerequisite. There is no accepted definition of a "comprehensive plan" which would be meaningful for present purposes, nor is it easy to frame one; if a definition were to be framed, it should include the standards which ought to be a prerequisite in any event. Certainly there should be comprehensive planning as a prerequisite, but the requirement of a specified, existing, regional "plan" may impose a rigid formality which will be undesirable and burdensome.

A regional unit of government, tentatively called the Metropolitan Development Commission, is proposed for a variety of reasons and purposes. Open-space projects of the sort we hypothesize entail land-use controls which may profoundly influence the development of the region. Obviously we should not develop such projects ad hoc; there must be some broad-based planning. It would seem desirable to have a central planning unit, representative of the counties and of state

105 Cf. Planning Commins of Bucks, Delaware, Montgomery, \& Chester Counties \& of Philadelphia, Recommendations for a Regional Parks System IN Southeastern PENNSYlvania (1959) (setting forth suggested park sites and cost estimates). 
government. Similarly, it would seem desirable, particularly insofar as federal or state funds are used, to assure that those funds are used wisely in accordance with the objectives of the Act and in accordance with a system of priorities.

Federal legislation on open-space preservation was probably intended to require that open-space projects aided by the national government be planned in accordance with regional needs as determined by a responsible regional unit; and it probably permits substantial savings where projects are actually supervised regionally. ${ }^{108}$ Obviously it is desirable-perhaps indispensable-to achieve these benefits. It would also seem desirable to centralize administration of the business of seeking and disbursing federal grants-in-aid and state appropriations for open-space purposes, and to unify and economize on other purely administrative and fiscal functions requiring continuing expert attention. Finally, from the standpoint of municipal finance, the creation of this public body to administer the regulations and pay sums due on guarantees may provide advantages. ${ }^{107}$

100 The new act provides that the Administrator, prior to making any grants for the acquisition of land, must find that "a program of comprehensive planning (as defined in section 701(d) of the Housing Act of 1954) is being actively carried on for the urban area." Housing Act of 1961, § 703(a) (2), 75 Stat. 184-85 (1961). This section, a 1959 amendment to the 1954 act, provides that such a program be carried on at the state and local level, aided by federal planning grants-in-aid. These grants, however, are conditioned upon the Administrator's receiving assurances that "reasonable progress in the development of the elements of comprehensive planning" is being made. 73 Stat. 678 (1959), 40 U.S.C. $\$ 461$ (d) (Supp. II, 1961).

Section 702 (a) of the new act permits federal grants-in-aid to provide $20 \%$ of the funds needed for the acquisition of open-space lands where "State or local public bodies" are involved in carrying out open-space programs. Where, however, the public body "(1) exercises responsibilities consistent with the purposes of this title for an urban area as a whole, or (2) exercises or participates in the exercise of such responsibilities for all or a substantial portion of an urban area pursuant to an interstate or other intergovernmental compact or agreement," the Administrator may enter into contracts committing the federal government to defray up to $30 \%$ of the costs. 75 Stat. 184 (1961).

107 Under Section 108 of our draft Open Space Act, the Commission is to make payments on behalf of the regulating political subdivision to owners of land in an open-space area, to the extent of their loss under the owner's guarantee. The Commission must provide for meeting these obligations by establishing a contingency fund, the amount of which is to be the total of local and federal appropriations, plus sums received from periodic state appropriations made for satisfying anticipated claims against the fund for a given fiscal period. The question may arise whether the act creates any indebtedness which must be charged against constitutional debt limitations of the state or county. See, e.g., PA. Const. art. IX, $\$ \S 8,10$. We believe not. While the obligation to pay regulated owners who have suffered loss is an obligation imposed on the county by law, it is a contingent obligation. No liquidated, enforceable obligation, and therefore no indebtedness for purposes of debt limitations, should exist until a regulated owner can establish a liquidated claim against his guarantee; and such an obligation should only become a debt if there is no fund from which it can be paid. See, e.g., Jones, Bonds AND Bond Securitres \&94 (4th ed. 1935); 15 McQuillan, Municipal Corporations $\$ \$ 41.18,41.23$ (3d ed. 1950); cf. Graham v. Philadelphia, 334 Pa. 513, 519-22, 6 A.2d 78, 80-81 (1939); Schuldice v. City of Pittsburgh, $251 \mathrm{~Pa} .28,95$ Atl. 938 (1915). Even assuming arguendo that the enactment of regulations does create an obligation which could be charged as "indebtedness" against the political subdivision, such indebtedness should be limited to the amount of claims that may reasonably be foreseen in a given period, $c f$. Addystone 
No doubt there would be objections to this proposal. The unhappy history of regional planning in some areas, such as southeastern Pennsylvania, and the assumed strong opposition to it, may be cited. The answer to this is that despite failures of the past, the need for cooperation in planning for major transportation needs, water resources development, and parks is now realized by more people than ever before. Indeed, it is difficult to see how a sensible inventory of many major open-space needs and a program to meet them can be devised except on a broad regional basis. Let it be emphasized, though, that the regional unit here proposed is essentially a planning and administrative unit, to be used at the option of existing subdivisions which choose to enact regulations.

A quite different objection would be that ad hoc regional units, dealing with only selected aspects of metropolitan problems, are undesirable because they may only compound the evils of Balkanization and retard development of a more adequate unit of metropolitan government with broader policy functions and powers. But we are probably a long way from the development of adequate machinery for metropolitan decision making, and the most likely place to begin is in the area of planning. The regional unit which we propose should have all the powers of a regional planning commission, and indeed should absorb or be built upon any regional planning commission in existence. We have put forth our proposal having in mind our own

Pipe \& Steel Co. v. City of Corry, $197 \mathrm{~Pa} .41,46$ Atl. 1035 (1900), which is the very amount of the contingency fund; thus no debt is created. Cf. Graham v. Philadelphia, supra. If the contingency fund established by the Commission appears inadequate to pay anticipated claims, and additional funds are not available, the political subdivision can always relax or repeal the regulations without incurring any obligation except actual damages or costs of litigation arising out of the regulations, or at least without incurring "debt" obligations. Cf. Mills v. Houck, 124 Cal. App. 1, 12 P.2d 101 (Dist. Ct. App. 1932). Compare Reinbold v. Commonwealth, 319 Pa. 33, 179 Atl. 571 (1935), with Philadelphia Appeal, $364 \mathrm{~Pa} .71,70$ A.2d 847 (1950).

Another question that may arise is whether creation of the Metropolitan Development Commission might violate constitutional clauses such as PA. CoNST. art. III, $\$ 20$, which reads:

The General Assembly shall not delegate to any special commission, private corporation or association, any power to make, supervise or interfere with any municipal improvement, money, property or effects, whether held in trust or otherwise, or to levy taxes or perform any municipal function whatever.

This clause must be read and interpreted in the light of its historical origins. Tranter v. Allegheny County Authority, $316 \mathrm{~Pa}$. 65, 173 At1. 289 (1934). It seems primarily designed to prohibit creation of public bodies which can incur indebtedness or impose taxes without being subject to electoral control, and to prohibit purely private corporations from being vested with power to control municipal funds and property. Lighton v. Abington Township, 336 Pa. 345, 9 A.2d 609 (1939); Wilson v. Philadelphia School Dist., 328 Pa. 225, 240-41, 195 At1. 90, 99 (1937). Public bodies which neither tax nor incur debts and which exercise essentially administrative dutieseven though these may entail considerable discretion-have been upheld. See, e.g., Dornan v. Philadelphia Housing Authority, 331 Pa. 209, 200 At1. 834 (1938) ; Tranter v. Allegheny County Authority, supra. 
area, which presently lacks such a unit, although it has made a promising start in the transportation field. The effort should be made to put some planning on a regional base; other regional planning functions can later be allocated to the unit created for open-space purposes or its functions otherwise merged within a new and broader unit. In any event it is the principle of regional planning, not the particular scheme set out here, which we think is important; draft legislation addressing itself to major regional open-space needs simply should not ignore this need.

Nevertheless, the actual power to impose regulations should devolve on an existing unit of government responsible to public control. Our draft enables counties and cities to enact the regulations described above in order to reserve land for open-space purposes-although these may not be the appropriate units in all states. It attempts to set forth general guides in the exercise of these powers. Before any open-space project is enacted, the county or city must make findings, supported by evidence adduced by its planning agency and confirmed by its governing body, to the effect that the undertaking will meet performance standards prescribed as a prerequisite to action.

Finally, the draft requires publication of an appropriate notice describing a proposed project and a public hearing on its feasibility. Evidence must be produced to support the project and its conformity to the standards. Opponents may challenge its necessity or legality if the claim is made that the standards were ignored or subverted. Judicial review is permitted, if the project is confirmed, but only on the ground that required procedures were not followed, or that findings were clearly unreasonable.

\section{Relation to the Federal Act}

Our proposal may not mesh well with Title VII of the Housing Act of 1961.108 Title VII grants-in-aid are authorized "to help finance the acquisition of title to, or other permanent interests in, . . . [openspace] land;" 109 the purposes for which grants are to be available seem to be limited to recreation, conservation, and the preservation of scenic and historic areas.

We think the federal law should be reappraised, both as to goals and as to methods. Indeed, it is ironic that its goals are now so narrowly drawn. Senator Harrison Williams, who introduced the original bill, ${ }^{110}$ and who was Title VII's strongest advocate, put extraordinary emphasis on the need to use open-space preservation 
as a method of controlling sprawl, channeling development, and implementing new and more daring concepts of "greenbelts." 111 President Kennedy, in his housing message, seems to have stressed these objectives. He told Congress:

Land is the most precious resource of the metropolitan area. The present patterns of haphazard suburban development are contributing to a tragic waste in the use of a vital resource now being consumed at an alarming rate.

Open space must be reserved to provide parks and recreation, conserve water and other natural resources, prevent building in undesirable locations, prevent erosion and floods, and avoid the wasteful extension of public services. Open land is also needed to provide reserves for future residential development, to protect against undue speculation, and to make it possible for State and regional bodies to control the rate and character of community development. ${ }^{112}$

The President's proposal for loans to help finance acquisition of land for "future public or private development" ${ }^{113}$ was unceremoniously removed when the Housing and Home Finance Agency's bill ${ }^{114}$ was taken up in the Senate committee. ${ }^{115}$ The proposal that open space be preserved to avoid economically wasteful use of land-to "prevent building in undesirable locations," to control the "rate and character" of "community development," and to avoid "wasteful extension" of services "116 —was rejected when the House restricted the proposed definition of "open-space land." Originally, it included "any undeveloped or predominantly undeveloped land, including agricultural land, in or adjoining an urban area which has: (A) economic or social value as a means of shaping the character, direction, and timing of community development; (B) recreational value; (C) conservation value in protecting natural resources; or (D) historic, scenic, scientific or aesthetic value." ${ }^{117}$ At the instigation of Congressman Rains, one of the managers of the Administration bill, the House-without any meaningful discussion-cut out the italicized language. ${ }^{118}$ The motive, quite possibly, was to save the bill from total defeat. The effect, it appears, was to change its stated objectives by deleting the

111107 Cong. REC. 1772-83 (daily ed. Feb. 9, 1961).

112 Hearings on Various Bills to Amend the Federal Housing Lazes Before a Subcommittee of the Senate Committee on Banking and Currency, 87th Cong., 1st Sess. 12-13 (1961).

113 Id. at 13.

114 S. 1671, 87th Cong., 1st Sess. (1961).

115 The bill reported out of the Senate Committee on Banking and Currency contained no loan provision. See S. 1922, 87th Cong., 1st Sess. (1961).

116 Hearings on Varions Bills to Amend the Federal Housing Lazes, supra note 112 , at $12-13$.

117 S. 1922, 87th Cong., 1st Sess. $\$ 606$ (a) (1961). (Emphasis added.)

118107 Cong. REc. 1039-40 (daily ed. June 22, 1961). 
very purposes which had previously been stressed by those who had given close study to the problem.

Of course it is quite possible that, even with this deletion, federal funds can still be used to create open areas which will serve the purposes envisioned by Senator Williams, the President, and the HHFA architects of the Administration bill. ${ }^{119}$ But the legislative history suggests, insofar as it suggests anything, that the purpose of the Rains "ripper" was "restrictive," that most Congressmen probably thought they were authorizing federal aid mainly for the acquisition of park and recreation lands. (We need "this open space for kids to play in" 120 was the typical line of argument.) In any event, the restrictive definition, coupled with this legislative history, may make it harder to develop the very kind of open-space planning which should warrant priority.

On the matter of methods, it appears that little consideration was given to the possibility of grants-in-aid to finance compensation in the type of scheme we have proposed. Title VII itself reflects what appears to have been the accepted premise: open space may be preserved by zoning and other regulatory land-use controls, by tax incentives, or by purchase of property interests; the first two methods may not be fully effective; so the need is for money to finance property purchases; the federal government should grant money for that purpose when it can be shown that the other devices will not work. ${ }^{121}$

If our arguments in this Article have merit, if there may be a better, more efficient, and less expensive way of reserving land, through regulation and compensation only for loss in value, then we think it is important that the federal law be reviewed. ${ }^{122}$

110 Compare the present statement of purposes in Title VII:

It is the purpose of this title to help curb urban sprawl and prevent the spread of urban blight and deterioration, to encourage more economic and desirable urban development, and to help provide necessary recreational, conservation, and scenic areas by assisting State and local governments in taking prompt action to preserve open-space land which is essential to the proper long-range development and welfare of the Nation's urban areas, in accordance with plans for the allocation of such land for open-space purposes.

Housing Act of 1961, §701(b), 75 Stat. 183 (1961). See also the "findings," in $\$ 701$ (a). The practical question may be whether the "scenic" values purpose can be construed broadly enough to include conservation of land where the primary goal is economic.

120 See 107 Cong. REc. 10358 (daily ed. June 23, 1961) (remarks of Congressman Rains); ibid. (remarks of Congressman Madden); 107 CoNG. REc. 10148 (daily ed. June 21, 1961) (remarks of Congresswoman Griffiths); id. at 10148-49 (remarks of Congressman Battin).

121 See Housing Act of 1961, §§ 702(a), 703 (b), 75 Stat. 184, 185 (1961).

122 In addition to the problems discussed in the text, we append here a few further comments and queries about Title VII to illustrate the difficulties posed by the legislation and the need for further study of the Federal Act.

The Locus of an Open-Space Program-The Meaning of Urban Areas. Title VII seems to be premised on the assumption that the federal funds to be expended are to help large towns, cities, and metropolitan areas meet their open-space needs. The "open-space land" to be purchased must lie "in an urban area." See Housing Act 
It is easy, of course, to criticize Title VII, when in fact its authors and advocates deserve high praise for accomplishing what they have-securing so novel a program in response to a problem which may be urgent, but is also difficult to define. But the point to be

of 1961, $\$ 706(1), 75$ Stat. 185 (1961). (Emphasis added.) Senator Williams' original bill said: "in and around urban areas." S. 858, 87th Cong., 1st Sess. \& 3(a) (1961). (Emphasis added.) The language of the HHFA revision, S. 1671, 87th Cong., 1st Sess. §104(2) (1961), which was carried over into S. 1922, 87th Cong., 1st Sess. $\$ 606$ (a) (1961), was: "in or adjoining urban areas." (Emphasis added.)

Section 706(2) defines "urban area" as:

[A]ny area which is urban in character, including those surrounding areas which, in the judgment of the Administrator, form an economic and socially related region, taking into consideration such factors as present and future population trends and patterns of urban growth, location of transportation facilities and systems, and distribution of industrial, commercial, residential, governmental, institutional, and other activities.

Housing Act of 1961, $\$ 706(2), 75$ Stat. 185 (1961). (Emphasis added.) It thus appears that the Administrator has very broad discretion indeed to decide what constitutes an "urban area" for the purposes of awarding grants. Consider, for example the metropolitan Philadelphia area, comprised as it is (under some calculations) of a tri-state, eleven or twelve county region. Should it be the "urban area" for purposes of Title VII? If it were, there would be serious difficulties in meeting the "planning requirements" discussed below. If the State of New Jersey sought grants to match its "Green Acres" appropriations, could land within the entire state be said to lie within an "urban area" and thus be eligible? Or, if the Delaware River Basin Commission, an interstate, ad hoc unit, sought grants-in-aid for the purchase of sites for water storage and recreation facilities, could lands in the entire "river valley" be an "urban area"? No additional standards or legislative history appear to guide the Administrator in deciding what is an "urban area." Perhaps the definition should depend in part on the size and character of the open space to be acquired and its function in respect to a metropolitan area.

Who May Apply. The Administrator may award a $20 \%$ grant to any "state" or "local public body" which he deems "capable of carrying out the provisions of this title." Housing Act of 1961, $\$ 702$ (a), 75 Stat. 184 (1961). Presumably, if other requirements are met, any "public body" within an "urban area" might be eligible -from the smallest borough to an ad hoc park or water resources development unit. $C f$. $\mathrm{Pa}$. Laws 1961 , act 614 , summarized in note 3 supra, under which small municipalities may, presumably, apply for grants to aid such projects as the purchase of small parks, provided only the "planning requirements" are met. It may be open to some doubt whether the federal program, as originally conceived, was intended to aid essentially neighborhood open-space ventures, as opposed to larger programs serving regional needs.

A "public body" which "exercises responsibilities . . . for an urban area as a whole" may receive $30 \%$. So may a body which, pursuant to a compact, "participates in the exercise of such responsibilities for all or a substantial portion of an urban area . . . Housing Act of 1961, §702(a), 75 Stat. 184 (1961). Again, the definition which the HHFA may assign to "urban area" becomes crucial: could a county qualify? The difference between $20 \%$ and $30 \%$ may mean a lot of open space.

Planning Requirements. Title VII requires, in $\$ 703$, as prerequisites to a grant: (1) that the open-space projects for which federal funds are sought be "important to the execution of a comprehensive plan for the urban area" and (2) that "a program of comprehensive planning (as defined in Section 701(d) of the Housing Act of 1954 [73 Stat. 678 (1959), 40 U.S.C. \$ 461(d) (Supp. II, 1961), amending 68 Stat. 640 (1954)]) is being actively carried on for the urban area." The Administrator may establish "criteria" for judging what constitutes a "comprehensive plan" for purposes of the first (if not the second) requirement. Unfortunately, it may be that there is no "comprehensive plan" or "planning" in the very counties that have the best and most available open space.

Note, too, that here again we are referred back to the question: what shall constitute an "urban area" for purposes of these particular requirements? Compare the President's statement that ". . . a prerequisite for Federal aid will be an effective and comprehensive plan for metropolitan or regional development." Hearings on Various Bills to Amend the Federal Housing Laws, supra note 112, at 13. (Emphasis added.) Suppose, however, that one aggressive county has a well-planned park 
stressed is this: left on the books as it is, the federal law may unconsciously dictate the form and substance of future state legislation in this field as well as planning and programming in response to it, and this will be unfortunate if experimentation with bolder yet in the long run more realistic approaches to the problem is deterred.

acquisition program and a $\$ 701$ planning grant in its treasury, and it now applies for funds; could the county itself be an "urban area" in order to meet the "planning requirements"? Cf. H.R. ReP. No. 447, 87th Cong., 1st Sess. 43 (1961), suggesting that it could. Note again that the definition of "comprehensive planning," drawn from the 1959 amendment to $\$ 701$ of the Housing Act of 1954, was probably not drafted with an "open-space" program in mind, and it may not be ideally conceived as a prerequisite to an open-space program. Detailed $\$ 701$ planning may be cumbersome and create more delay as the "urban area" becomes larger. There may still be a need, in any event, for some more specific standards to guide and govern decisions to allocate areas of undeveloped land within a metropolis for open-space purposes rather than for housing, industry, or other uses. And would it not also be advisable to require procedures within the planning process which would promote grassroots debate and enable affected citizens or groups to be heard in the decision-making process? $\quad C f$. Note, 108 U. PA. L. REv. 534, 540, 569-75 (1960) (local hearings under federal highway legislation).

In its "Initial Statement of Policies to Govern Grants for Open Space Land," August 17, 1961, a somewhat unoriginal document which repeats the statutory jargon virtually verbatim, the HHFA, in this one particular, struck out on its own and recognized that progress in "comprehensive planning" is slow; and it had this to say, inter alia:

In cases where there is a necessity to act promptly to avert loss of an openspace area essential to the proper long-range development of the community, a grant may be approved even though a comprehensive plan has not been completed. The applicant must demonstrate that the proposed open-space use would be a reasonable part of any probable comprehensive plan for the community.

Id. at 3. Apparently, however, the HHFA will require that at least "a program" of $\$ 701$ "planning" be "actively" underway for the "urban area" before any funds will be made available. See ibid.

Costs, Priorities, and Efforts to Reduce Costs. The Administration estimated that $\$ 100$ million was necessary to launch an adequate open-space program within its first year. See Hearings on Various Bills to Amend the Federal Housing Laws, supra note 112, at 13 (President's Housing Message). Congress has chopped this to $\$ 50$ million. See $\$ 702(\mathrm{~b})$. The costs of "open-space" lands which may be needed within any one metropolitan area are inestimable, which suggests that once the program gets underway, difficult problems may arise in terms of deciding what kinds of projects and applicants should get priority. Even within a single metropolitan area there may be such problems. Should all applicants receive equal treatment? How are the comparative merits to be evaluated? And in accordance with $\$ 703$ (b), how shall the Administrator take the necessary action "to assure that local governing bodies are preserving a maximum of open-space land, with a minimum of cost," using such alternative methods as "zoning and subdivision provisions," "special tax" incentives, and acquisition of tax delinquent lands? Are there available in the regional offices of the HHFA the necessary skills for making such determinations? Should an applicant be penalized because its state legislature has enacted inadequate enabling legislation for these purposes? 


\section{APPENDIX}

\section{TENTATIVE DRAFT OF AN OPEN SPACE ACT*}

\section{INTRODUCTION}

\section{$\S 1$. Findings [text omitted]}

[Enumeration of local needs to justify enactment of statute and explain its "public purpose."]

\section{§2. Scheme of the Statute [text omitted] \\ [Brief description of the plan and functions of the Act.]}

\section{§ 3. Purposes}

(a) The powers created in this Act may be used to achieve the following purposes: To secure open-space areas, within metropolitan areas, which will promote the economic use of land and the economic development of facilities, services, and improvements necessary for urban community living in metropolitan areas by:

(1) directing new urban development into areas in which the required public facilities and services can most efficiently and economically be provided; or

(2) restricting or preventing new urban development in areas where it will impose unreasonable costs for required public facilities or services; or

(3) retarding development for fixed periods of time in areas where it is not yet timely because of lack of adequate public facilities or services or other necessary improvements and because the costs which the extension, construction, operation, or improvement of such facilities and services would impose on the area are unreasonable by comparison with its present resources; or

(4) reserving land needed for future public facilities (such as educational institutions, hospitals, airports, and major highway facilities); or

* This draft "Act" illustrates a new legal approach to open-space preservation and planning. It is not complete in a number of respects indicated and is intended primarily as a device for drawing attention to the problems which require solution. As originally prepared for PenJerDel Inc. and the Institute of Legal Research of the University of Pennsylvania, those sections here presented in synopsis were drafted in full. Their inclusion here in abbreviated form is to avoid repetition of points which, hopefully, were fully made in the body of the Article to which this Act is appended. Copies of the complete draft may be obtained from the authors. 
(5) reserving substantial areas of undeveloped land to be held as sites for private commercial or industrial facilities which, in accordance with the requirements of this Act, are shown to be needed in the future to service residential areas or to promote the economy of the metropolitan region as a whole; or

(6) conserving land suitable for recreational uses consistent with projected future recreational needs; or

(7) preserving less congested land areas in the metropolitan area which could be used, in part, to achieve economies in planning and locating arterial transportation facilities; or

(8) preventing floods, flood damage, and soil erosion; or

(9) conserving areas needed for water supply; or

(10) preserving productive forest and agricultural lands lying within the metropolitan area.

And in conjunction with any of the above purposes, to secure any of the following additional purposes:

(11) to preserve undeveloped areas of land in order to prevent continuous and complete urban use of land within the metropolitan area, to separate distinct urban communities (or groups of communities) within the metropolitan area, and thereby to promote more aesthetic, distinctive, and cohesive development of these communities or groups of communities; or

(12) to preserve accessible areas of natural scenic beauty within the metropolitan area; or

(13) to promote recreation through (A) public acquisition of ownership in fee or of property interests in lands in open-space areas or (B) enactment of regulations pursuant to powers authorized in this Act which will permit limited public recreational uses of private lands consistent with continued private ownership; or

(14) to preserve significant architectural, historical, and natural landmarks and adjacent areas of scenic value; or

(15) to preserve natural habitats for wildlife.

(b) The Legislature, after careful revièw, has concluded that these purposes are not only proper public purposes consistent with the Constitution of this State, but their realization, to the extent permitted by the powers, limitations, and standards set forth in his Act, are of great importance to the $x \%$ of the population of this State who now live in metropolitan areas. 


\section{§4. Planning Standards}

(a) Planning for an open-space project shall relate to the project such factors as future population trends, planned transportation, industrial, and commercial facilities, and projected needs of land for an adequate supply of decent housing.

(b) Planning for open-space projects shall also conform to the following standards:

(1) The studies and plans must be adequate to support findings that the open-space project will serve the purposes for which such project may be undertaken pursuant to $\S 3$, and

(2) The studies and plans shall support the finding that, notwithstanding the open-space project, there will remain within the metropolitan area where the project is situated an adequate supply of land for decent housing at reasonable cost and for other facilities necessary for the proper development of the area, and

(3) Where relevant to the purpose of the project, the studies and plans shall support the finding that its location and other transportation conditions make the land sufficiently accessible that the public benefit sought may be realized by a substantial part of the metropolitan population, and

(4) Where the purpose of the open-space project is to preserve land for future development of public or private facilities, the studies and plans shall support a detailed finding of the advantages that will accrue to adjacent communities and to the metropolitan area as a whole, both immediately and in the future, and

(5) Where the purpose of the open-space project is to retard development, the studies and plans shall support the finding that the public resources affected are inadequate to bear the burden of immediate development and that a plan exists which [permits] [provides for] gradual development of the area over a [fixed] [reasonable] period of time.

(6) Such studies shall show the estimated costs of the project.

\section{§ 5. Definitions [text omitted]}

[Definition of "open space," "open-space area," "political subdivision" (as counties and large cities only in our proposal), "subdivision," and "tract."] 


\section{ARTICLE I. METROPOLITAN DEVELOPMENT COMMISSION}

$\S 100$. Metropolitan Area Defined [text omited]

$\S$ 101. Metropolitan Development Commission Created [text omitted]

$\S$ 102. Members of Commission [text omitted]

[Selection, salaries, and term of office of Commissioners.]

§ 103. Executive Director and Staff [text omitted]

$\S 104$. Powers of Commission

The Commission is authorized:

(a) to engage in such planning, including comprehensive planning, for the metropolitan region as a whole, as may be necessary to effectuate the purposes of this Act;

(b) to authorize political subdivisions to enact open-space regulations in accordance with procedures and powers granted in Article II;

(c) to cooperate with the planning and other agencies and governing bodies of the State and political subdivisions to effectuate the purposes of this Act;

(d) to cooperate with governmental agencies of other states to plan open-space projects which will promote the purposes of this Act;

(e) to receive grants and appropriations from the State and Federal governments, political subdivisions, or any other governmental agencies or private sources to carry out the purposes of this Act;

(f) to establish and maintain contingency funds for each openspace project in order to guarantee the damages and compensation costs incurred by political subdivisions in exercising powers vested in them by this Act;

(g) to pay on behalf of each political subdivision obligations which it may incur to owners of land pursuant to Articles III and IV;

(h) to assist political subdivisions in maintaining records and performing administrative duties necessary to carry out this Act;

(i) to assist political subdivisions in doing all other work which needs to be done to effectuate the purposes of this Act; authority.

(j) to exercise all powers necessary to carry out the foregoing 
$\S 105$. Board of Review-Appointment and Tenure [text omitted]

[Powers of the Board are set forth in Articles III and IV.]

$\S 106$. Planning of Open-Space Projects To Conform to Purposes and Planning Standards of This Act [text omitted]

[Commission and political subdivisions to be guided by $\S \S 3$ and 4 .]

\$107. Procedure for Initiating and Implementing Open-Space Projects [text omitted]

[For each project the Commission and political subdivision will jointly undertake studies and prepare necessary materials; the Commission will seek Federal grants-in-aid; the political subdivision will then hold hearings pursuant to Article II; following hearings and upon approval by the political subdivision, the Commission may formally authorize the project, and the subdivision shall thereupon enact regulations pursuant to Article II.]

$\S 108$. Financing of Open-Space Projects-Responsibilities of Commission and Political Subdivisions [text omitted]

[Each project to be financed by estimating total possible costs, securing appropriations based on a fixed percent of total possible costs from Commission, political subdivisions, and Federal government, using these appropriations to establish a contingency fund to pay actual costs incurred; Commission to administer contingency fund with power to withdraw its funds where possible and use them for other projects.]

\section{ARTICLE II. ENACTMENT OF OPEN-SPACE REGULATIONS}

$\$ 200$. Scope of This Article [text omitted]

$\S 201$. Power of Political Subdivisions To Enact Regulations-Conflicts Between Regulations and Other Ordinances [text omitted]

$\S$ 202. Hearing Prior to Enactment of Regulations [text omitted]

[Political subdivision must hold hearings prior to enactment of regulations; notice by publication of plan and proposed findings and regulations; "interested" parties may be heard in person and by written objections.]

§ 203. Enactment of Regulations [text omitted]

[Political subdivision may adopt or modify regulations and appropriate its share of project funds to Commission.] 
§ 204. General Form and Content of Open-Space Regulations

(a) The regulations shall:

(1) contain such detailed controls over land use, including public uses, as are necessary to effectuate the purposes of the openspace project;

(2) specify the modifications which will not interfere with the purposes of the open-space project and which may be made by the Board of Review upon petition of owners of property interests in the open-space area;

(3) specify other modifications, consistent with the purposes of the open-space project, which may be made from time to time by the political subdivision enacting the regulations;

(4) contain provisions designed to encourage preservation of the value of regulated property for permitted uses;

(5) contain provisions governing the conduct of public sales which are to be held under the supervision of the Board of Review pursuant to the provisions of $\S 303$; and

(6) indicate generally what other municipal land-use controls and municipal laws relating to the use of land and structures may remain in force or be enacted and enforced notwithstanding the regulations.

(b) Where an open-space area is regulated for the purposes described in $\S \S 3(a)(3)$, (4), and (5), the regulations may contain a schedule providing for release of the area from regulations in accordance with $\S 207$.

\section{§ 205. Judicial Review [text omitted]}

[Interested property owners may petition the court to determine whether the hearing held under $\$ 202$ conformed to the requirements of that section, whether the findings are not against the manifest weight of the evidence, and whether the regulations substantially reflect the purposes of the project.]

\section{§ 206. Changes in Regulations [text omitted]}

[Procedure for modifying regulations by action of the Board of Review or the political subdivision, following procedure in accord with $\S 202$.

\section{§ 207. Repeal of Regulations}

Repeal, here, means action taken to remove part or all of the land situated within the open-space area from the provisions of this Act. 
Regulations may be repealed by the political subdivision which has enacted them as follows:

(a) Where the purpose, or one of the purposes, of the open-space project is to retard development under $\S 3(a)(3)$ or to reserve land under $\S \S 3(a)(4)$ and (5), and the regulations contain a detailed schedule providing for the removal of the area, or of specified portions thereof, from the regulations, the political subdivision may repeal the regulations by (1) adopting findings that such repeal is in accordance with the schedule, (2) enacting, or assuring that the political subdivision normally charged with this power enacts, zoning and other land-control ordinances which may have expired or been superseded since the enactment of open-space regulations, (3) securing the approval of the Metropolitan Development Commission and, (4) declaring the regulations repealed and releasing the area from the provisions of this Act.

(b) [Text omitted]

[Where no advance provision has been made for deregulation, the repeal procedure requires findings showing wherein regulation is no longer needed and a public hearing as under $\S 202$ before the repeal of regulations.]

\section{ARTICLE III. COMPENSATION AND DAMAGES}

\section{§300. Market Value-Owner's Guarantee}

(a) In order to assure fair compensation to all owners of interests in real property located in an open-space area and in order to guarantee that such owners may freely withdraw from the area, each tract of land existing when the open-space regulations become effective shall be assigned, for purposes of computing damages under $\S 302$ and compensation under $\S 303$, a value established as provided in $\$ \S 400-06$ of this Act.

(b) The value assigned pursuant to subsection (a) of this section shall be known as the "owner's guarantee."

(c) Subject to the provisions of $\S 305$ of this Act, the owner's guarantee established for each tract of land shall, when necessary to effectuate the provisions of this Act, be apportioned among the several interests in such tract, whether existing on the effective date of the regulations or thereafter created, in accordance with the same principles as are applicable to the apportionment of a unit condemnation award among the several interest holders in the unit condemned. Such apportionment shall be made as provided in $\S 408$. In applying these principles, an adjustment shall be made for the effect on the relative values of the 
several interests in the tract of improvements, if any, made by the owners thereof since the regulations came into effect and for the effect thereon of the regulations themselves, and the guarantee shall be apportioned, as nearly as practicable, as if no such improvements or regulations had existed.

(d) At such time or times when damages or compensation are computed and paid under $\S \S 302$ and 303 , the owner's guarantee established with respect to any tract of land shall:

(1) be adjusted to reflect changes in the value of the dollar by reference to the Consumer's Price Index prepared by the Bureau of Labor Statistics of the United States Department of Labor, and

(2) be reduced by the amount of each award of damages or compensation paid, provided that in the case of compensation paid following upon a public sale under $\S 303(\mathrm{~b})$, such reduction shall not exceed the difference between the owner's guarantee apportioned to the interest sold and the purchase price paid therefor at such public sale. Upon later apportionments of the guarantee among the several interests in the tract, if any, the limitation of $\S 303(\mathrm{~b})$ concerning postregulation purchasers of open-space land shall be observed, and the reductions of the guarantee made on account of payment of damages shall be charged to the interests in respect of which such payments were made.

\section{COMMENT}

The detailed provisions for the establishment of the owner's guarantee have been deferred to Article IV in order that the broad contours of the scheme proposed by the Act not be obscured by a mass of detail.

\section{Subsection (b)}

This subsection defines "owner's guarantee" as the value established under the provisions of $\S \S 400-06$. Under $\S 401$, this value is the fair value of the property existing immediately before the regulations are imposed. For detailed discussion, see Comment to $\$ 401$.

\section{Subsection (c)}

This subsection provides for an apportionment of the owner's guarantee established with respect to any tract among the several interests, if more than one, existing in the tract.

The apportionment is to be governed by "the same principles as are applicable to the apportionment of a unit condemnation award among the several interest holders in the unit condemned." This is consonant with the function of the guarantee which is to secure to the various interests existing in any tract of land at the time the declaration of open space is adopted the same compensation as would then be payable for a taking in fee simple absolute.

However, the scheme of the Act is to establish the guarantee, but to leave to the individual interest holder (subject to the condition of a public sale of his interest) the timing of its realization. Thus the apportionment of the guar- 
antee must respond to subsequent changes in the alignment and relative value of such interests. Subsection (c), therefore, provides that the guarantee shall be apportioned "when necessary to effectuate the provisions of this Act" and, further, that the apportionment, on such occasions, shall be made among the several interests "whether existing on the effective date of the regulations or thereafter created." In short, the guarantee remains in "semianimated suspension" with regard to each tract, to be drawn on by the interest holders in that tract, for the purpose of measuring compensation and damages claimed under the provisions of the Act. It is to be permanently apportioned only upon subdivision of the tract, which is governed by $\S \S 305$ and 409 .

The responsiveness of the owner's guarantee to changes in the alignment and relative value of the several interests in the tract should not go to the length of permitting one interest holder to improve another out of his just proportion of the guarantee. Nor should it permit the regulations themselves to affect the allocation of the guarantee. In point of fact, there are expected to be very few situations in which the value of an improvement in a unit of fee ownership inures to the benefit of the various interests therein in different proportions than does the value of the fee. Similarly, there will be few situations in which the relative value of the interests in the fee will be changed by the regulations. (For discussion of the peculiar position of landlord and tenant, see Comment to $\S 303(d)$ ). Subsection (c), however, contains a provision designed to prevent any inequities in this respect.

Subsection $(d)(1)$

The owner's guarantee is the fair value of the property established as of a certain date, stated in dollars. To protect the deferred compensation scheme of the Act, the guarantee must respond to changes in the value of the dollar. There would be little incentive for property owners to remain in the area and thus defer their claim for compensation in return for a guarantee stated in fixed dollars of possibly diminishing purchasing power.

\section{Subsection $(d)(2)$}

This subsection provides that the owner's guarantee available in respect of any tract of land shall also be reduced by each award of damages or compensation paid under $\S \S 302-03$. This assures that the aggregate compensation or damages payable with respect to any tract shall never exceed the guarantee established for that tract. (Certain limitations imposed in this subsection and in $\S 303(b)$ are discussed in the Comment to the latter section.)

\section{§ 301. Recording of Owner's Guarantee}

(a) The owner's guarantee established with respect to any tract of land shall be recorded by the governing body of the political subdivision in public records kept for this purpose. The records shall contain a description of the tract to which the guarantee pertains, the date upon which the guarantee was established, and the amount of the guarantee.

(b) On each occasion when compensation or damages are paid under $\$ \S 302$ and 303 , there shall be recorded the guarantee for the whole tract (adjusted as provided in $\$ 300(\mathrm{~d})$ ) with reference to which the damages and compensation were computed, together with the amount of such damages or compensation by which $\S 300(\mathrm{~d})(2)$ re- 
quires that the guarantee be reduced, the names of the persons to whom such damages and compensation were paid, and the date on which the guarantee was adjusted and damages or compensation computed.

(c) Except as provided in subsection (b) of this section, the amount of the guarantee shown on the records is not required to be adjusted periodically for changes in the value of the dollar, but the records shall contain an appropriate notation calling attention to the provision of $\S 300(d)(1)$ of this Act.

\section{\$302. Petition for Damages}

(a) Within six months after the enactment of regulations for an open-space area, any holder of a property interest in such area may petition the Board of Review for a determination and award of damages limited as follows:

(1) The amount of damages shall be the difference between the value of the claimant's interest restricted to the purposes for which the land was actually being used when the regulations were adopted (including the uses which the claimant was then under a bona fide binding legal obligation to make) and the value of his interest restricted to or by the uses permitted under the regulations.

(2) The amount of damages which may be awarded to any one claimant shall in no instance exceed the owner's guarantee established for or apportioned to his interest. But this limitation does not apply to tenants of leasehold interests in open-space land.

(b) Within six months after amendment of regulations enacted for an open-space area, any holder of a property interest in such area may petition the Board of Review for a determination and award of damages limited as follows:

(1) The amount of damages shall be the difference between the value of the claimant's interest restricted to or by the uses permitted under the regulations prior to amendment and the value of his interest restricted to or by the uses permitted under the regulations as amended.

(2) The amount of damages which may be awarded to any one claimant shall in no instance exceed the owner's guarantee established for or apportioned to his interest. But this limitation does not apply to tenants of leasehold interests in open-space land.

\section{Subsection $(a)(1)$}

\section{COMMENT}

Possible change in the uses is not to be considered unless the owner is under a bona fide binding obligation to make such change at the time the regulations were enacted. Thus a contract to sell to a developer entered into 
in expectation of the regulations for the purpose of claiming damages will not be compensated under this subsection; the owner and developer will be relegated to a claim for compensation under $\S 303$.

\section{Subsection (b)}

The measure of damages upon amendment to the regulations is not confined, as it is under subsection (a), to loss occasioned to existing uses. Rather, the measure of damages is the loss in value of the land restricted to permitted uses. The purpose of this subsection is to encourage the market at the regulated level. Purchasers in the area would be less willing to pay the best price for the property at the regulated level if exposed to the possibility of change in that level without compensation except through a public sale and realization of a guarantee. The effect of a failure to extend the protection offered by subsection (b) can be illustrated as follows:

Tract $A$ possesses an owner's guarantee of $\$ 60,000$. The optimum market value of the regulated Tract $A$ has reached $\$ 70,000$. However, no purchaser would be willing to offer $\$ 70,000$ against a noncompensable possibility that a later amendment to the regulations will depress the regulated value of Tract $A$. For example, if the amendment depresses the value of Tract $A$ to $\$ 60,000$, the purchaser who has paid $\$ 70,000$ has lost $\$ 10,000$. This is so because he can only hope to realize $\$ 60,000$ on the guarantee.

The effect of subsection (b) is to extend to him the right to claim damages of $\$ 10,000$. This award will, of course, reduce the guarantee to $\$ 50,000$, but the guarantee is not significant to the purchaser since, by definition, the market value of Tract $A$ is still $\$ 60,000$. If there are any further amendments to the regulations, the purchaser can draw on his guarantee until it is completely exhausted. At that point he does stand the chance of losing the $\$ 10,000$ by which his offer exceeded the guarantee for Tract $A$. But it is so unlikely that this point will ever be reached that the chance should detract very little from the intended effect of this subsection.

\section{$\S$ 303. Owner's Guarantee-Compensation}

(a) Subject to the provisions of $\S 305$, dealing with subdivision of existing tracts of land, and subject to the regulations then in force in the area, the owner of any property interest located in an open-space area may exercise all his right of ownership therein including the right to sell, lease, give, or devise his interest or any lesser interest known to the law.

(b) Upon a showing by the owner of an interest in land which was in existence on the effective date of the open-space regulations, of a diligent effort to sell his interest at the net price which he reasonably believed to be equal to the owner's guarantee allocable to such interest, the Board of Review shall issue an authorization to such owner to sell the interest at a public sale, and, upon filing with the Board of Review proof of the price obtained at such sale, the owner shall receive from the political subdivision imposing the regulations compensation in an amount equal to the difference between the net proceeds received at the sale and the owner's guarantee established for or apportioned to his interest as provided in $\S 408$. The foregoing shall apply to owners of 
interests coming into existence or purchased after the effective date of the regulations, except that in the case of a public sale the owner's guarantee available to the purchaser at such sale and those claiming under him shall be the owner's guarantee computed as provided in $\S 300$ or the purchase price paid at such sale, whichever is lower.

(c) No compensation shall be paid for any diminution in the value of the property attributable to: (1) the owner's willful failure to preserve the value of the property for permitted use; (2) casualty loss; (3) voluntary severance by the claimant, or by his predecessors in title, of natural resources which enter into the value of the property for purposes of establishing the guarantee.

(d) A tenant of a leasehold interest, whether such interest existed when the regulations came into effect or was thereafter created, shall have no right to compensation under subsection (b) of this section, but he may claim damages under $\$ 302$ limited as therein provided. The compensation of a landlord is governed by the provisions of subsection (b) of this section.

(e) Where the fee in open-space land is held in successive legal interests or is subject to successive equitable interests under a trust whose trustees are not empowered to sell the fee, a court of equity may empower such trustees to sell, or may order that title to the property vest in trustees appointed by the court and empowered by it to sell, the entire fee simple absolute interest in the open-space land under the provisions of subsection (b) of this section, the proceeds and compensation to be invested by such trustees for the benefit of the successive owners as their interests appear.

\section{GOMMENT}

The purpose of this provision, taken together with the establishment and definition of the owner's guarantee ( $\$ 300$ and 401 ), is (1) to limit recovery for development value to that value existing on the date when the regulations were imposed and (2) to postpone compensation for development value until the owner is willing to terminate his interest in the open-space land through public sale.

It is grossly unfair to require the community to pay for loss of development value without regard to the question whether the owner is prepared to give up his present uses and develop. This is one of the main failings of the "development rights acquisition" approach. Moreover, that approach lends itself to abuse by powerful members of the community who, through this device, may not only secure a desirable assurance of the restricted, "unspoiled" character of their property but also draw upon the public treasury for the "development value" supposedly lost by them. On the other hand, the development rights approach may be unfair to the ownex in that the remaining value of his property is not guaranteed against future depression because of inability to develop. By means of the owner's guarantee, the owner is protected against any loss in the value of his property existing on the date of the declaration of open space, including a general drop in the real estate market. In return for this guarantee, 
it seems fair and appropriate to require, as a condition to compensation, that the owner be prepared to give up his interest at a public sale. This condition, confined as it is to development value, see $\S 302$, is reasonable not only because it protects the community against payment of compensation for real or imaginary values which the owner may have had no intention to realize, but also because the value to be compensated is one which is normally realized by the owner through sale to a developer.

\section{Subsection (b)}

Section 204(a)(5) provides for the adoption of regulations governing the "public sale" to be held under subsection (b). This method of assuring that the community is protected against agreements which are designed to milk the guarantee is subject to the objection that public sales, as traditionally envisioned, do not normally result in best prices. It is possible, however, that the required regulations will define "public sale" in nontraditional terms; any form of supervised sales procedure which would guarantee to the community that the property would be sold at approximately the price which the property would command if its owner used his best efforts to sell it would satisfy the requirements of the Act. Our purpose at this point is not to solve the problem of preventing the milking of guarantees, but to call attention to it.

Under subsection (b) the protection of the owner's guarantee is extended to postregulation purchasers in the open-space area. The extension is intended to encourage purchasers in the area to offer the fair value of the property at the regulated level, thus assuring that the community will be required to absorb only the difference between the fair value of the property when the regulations were imposed and the market value of the property at the regulated level. If the guarantee were not extended to purchasers in the area, they would be outside the scheme of the Act, and it might be argued that as to them the regulations have no more force than do noncompensable zoning regulations. ${ }^{1}$ Subsequent amendments to the regulations would pose additional problems. Therefore, subsection (b) extends the owner's guarantee to postregulation purchasers of interests in the open-space area. However, as to purchasers at a public sale and those claiming under them, the guarantee is the existing guarantee apportionable to the interest or the purchase price paid at such sale, whichever is lower. This limitation is necessary to aid the proper apportionment of the guarantee.

The same reasoning necessitates the limitation imposed in $\$ 300(d)(2)$ on the amount by which the owner's guarantee is to be reduced when compensation is paid to the vendor at a public sale. To illustrate the purpose of these limitations we may take an unusual case as follows: Tract $A$ is owned by $T_{I}$ and $T_{2}$ as tenants in common (or as joint tenants). The owner's guarantee established for Tract $A$ is $\$ 60,000$. $T_{2}$ offers his interest for sale for $\$ 30,000$ (his share of the guarantee). Having made a bona fide effort to sell at that price he pursues his right to a public sale under $\$ 303(\mathrm{~b})$. $T_{2}$ 's undivided onehalf interest in Tract $A$ is sold to $P$ for $\$ 25,000$. The costs of the public sale are $\$ 300$. The net proceeds of the sale, received by $T_{2}$, therefore, are $\$ 24,700$. The compensation payable to $T_{2}$ is $\$ 5,300$ (the difference between the owner's

1 It is doubtful how much a purchaser is precluded from attacking a zoning ordinance because he purchased subject to the regulation. See Bolger v. Village of Mount Prospect, 10 IIl. 2d 596, 141 N.E.2d 22 (1957) ; Vernon Park Realty, Inc. v. City of Mount Vernon, 307 N.Y. 493, 121 N.E.2d 517 (1954). Compare Aschenbach v. City of Plainfield, 121 N.J.L. 598, 3 A.2d 814 (Sup. Ct.), aff'd, 123 N.J.L. 255, 8 A.2d 579 (Ct. Err. \& App. 1939); Application of Devereux Foundation, 351 Pa. 478, 41 A.2d 744, appeal dismissed for zuant of a substantial federal question, 326 U.S. 686 (1945). See generally Note, 109 U. PA. L. REv. 992, 993-97 (1961). 
guarantee apportioned to his interest and the net proceeds received by him at the public sale).

If the owner's guarantee established for Tract $A$ were required to be reduced by the amount of compensation paid to $T_{2}$, the remaining guarantee would be $\$ 54,700$. P's share of the guarantee remaining is $\$ 27,350$ ( $1 / 2$ of $\$ 54,700)$ or the purchase price paid by him $(\$ 25,000)$ whichever is lower (limitation of $\S 303(\mathrm{~b})$ ). Thus, $P$ 's share of the remaining guarantee is $\$ 25,000$. $T_{I}$ 's share of the remaining guarantee is $\$ 29,700$ (\$54,700 minus $\left.\$ 25,000\right)$. Thus, if the owner's guarantee established for Tract $A$ were required to be reduced by the amount of compensation paid to $T_{2}, T_{1}$ would, in effect, suffer a reduction of his guarantee equal to the costs of the public sale.

Section $300(d)(2)$, in effect, requires the community to absorb these costs. This seems fair, because the public sale is designed to protect the community against private arrangements whose purpose is to exploit the guarantee. Consideration should be given to reducing the compensation payable under $\S 303(\mathrm{~b})$ by the cost of the public sale in cases where the sale is to the vendor or to members of his immediate family.

Section $300(\mathrm{~d})(2)$ contains an additional limitation which may come into play in the case of coowners. Normally, in an action for damages for injury to land held in coownership, all the coowners are necessary parties; one coowner may not sue for his proportionate share of the damages unless the others have released their claim. 4 Powell, REAL Property $\$ 606$ (1954). In a few jurisdictions, notably Massachusetts, statutory provisions permit suit by one coowner for his proportionate share of the damages. Mass. ANN. Laws ch. 231, $\S 3$ (1952). In such jurisdictions, if one coowner has recovered his proportionate share of the damages allowable under $\$ 302$, the remaining guarantee should not thereafter be apportioned equally between him and the other coowners. Section $300(d)(2)$ provides for this situation.

\section{Subsection (c)}

Valuation for purposes of establishing the owner's guarantee includes the value of improvements on the property. $\$ 401(a)$. There is no provision in the Act for adjustment of the guarantee to account for depreciation on such improvements. It is recognized that, because the guarantee is to be adjusted for changes in the value of the dollar, $\S 300$ (d)(1), the absence of any adjustment for depreciation will tend to increase the compensation payable under this section. Offsetting this tendency, however, is the provision of $\S 204$ (a)(4) calling for regulations designed to preserve the value of the property for permitted uses. While an attempt to force the owner to maintain the property beyond his financial means is impractical as well as open to serious objection, it is expected that the regulations may require more than minimum repair and husbandry. No direct enforcement of such regulations is provided. Instead, this subsection denies compensation for loss due to the owner's willful failure to meet the requirements set by the regulations. Notwithstanding the effect of these provisions, some value will be lost through the passage of time, for example, through obsolescence. It was felt, however, that an attempt to protect the community against payment for such loss would present administrative difficulties outweighing any savings secured.

This subsection, however, contains provisions designed to protect the community against payment of compensation for casualty losses or diminution in value due to voluntary severance of natural resources occurring after the guarantee is established. Neither of these limitations on compensation will come into play very often. The amount of the guarantee, it will be noted, is not affected. The justification of this approach to casualty loss and severance of natural resources, as well as of the absence of any adjustment for deprecia- 
tion, is that the presence of an unaffected guarantee will encourage restoration. This justification is applicable to severance of natural resources, because, it is believed, that the only resource affected by this limitation will be standing timber. Mining and drilling will not ordinarily be permitted in an openspace area.

\section{Subsection (d)-The Position of the Tenant}

The tenant cannot be required to sell his interest at a public sale as a condition to compensation. The right to sell or assign a leasehold interest is normally subject, by the terms of the lease, to the landlord's assent.

Consideration was given to permitting the tenant to claim immediately the amount of any loss in value of his leasehold not in excess of the owner's guarantee allocable to his interest. However, by $\S 300$ (c) the owner's guarantee would be apportioned to the tenant "in accordance with the same principles as are applicable to the apportionment of a unit condemnation award among the several interest holders in the unit condemned." On these principles, the tenant would be entitled to a portion of the guarantee only in cases where the lease is favorable to him. For, although there is some confusion on the point, see City of Ashland v. Price, 318 S.W.2d 861 (Ky. 1958), the generally accepted view is that the tenant is entitled only to a portion of the unit condemnation award which is equal to the amount by which the fair value of his unexpired leasehold exceeds the present worth of the rentals reserved for the remainder of the term, see New Jersey Highway Authority v. J. \& F. Holding Co., 40 N.J. Super. 309, 123 A.2d 25 (Super. Ct. 1956). Where the rents reserved in the lease exceed the fair rental value of the property, the tenant would be deprived of any compensation because he would not be entitled to any of the unit award in condemnation. However, in the case of outright condemnation, the tenant is relieved of his obligations under the lease, whereas, under existing authority, it is doubtful that he would be relieved from his obligations under the lease by the imposition of the open-space regulations. See 1 AMERIGAN LAW OF PROPERTY $\$ 3.104$ (Casner ed. 1952) (frustration of purpose). Since the fee is not in fact condemned, and the tenant is not likely to be relieved of this obligation under the lease, it would be grossly unfair if he were restricted in his claim for loss resulting to him from the imposition of the regulations to the owner's guarantee apportionable to his interest. Thus, the first step, in justice to the tenant, would be to relieve him of the requirement of a public sale and to allow him to claim compensation without reference to the guarantee allocable to his interest.

What, then, would be the proper measure of his compensation? He might be given the right to claim damages equal to the loss in the value of his unexpired leasehold interest. This measure of damages was rejected because it contains some of the objectionable features of the "development rights" approach. Where the lease itself does not define its purposes, such a measure of damages would encourage the tenant to claim for his leasehold unlikely development possibilities and pass them off as immediately planned or intended by him. True, the law of valuation in eminent domain has learned to handle the question of speculative values, see Gilleland v. New York State Natural Gas Corp., 399 Pa. 181, 159 A.2d 673 (1960), but the dictates of reason have not always prevailed, see St. Agnes Cemetery v. State, 3 N.Y.2d 37, 143 N.E.2d 377, 163 N.Y.S.2d 655 (1957).

Subsection (d) takes the position that the present provision for damages under $\$ 302$ is ample protection for the tenant. The measure of damages under $\S 302$ is the injury to existing uses, including uses which the tenant is under a bona fide binding legal obligation to make at the time when the regulations were imposed. Thus, if the lease requires the tenant to develop the property 
and such development is restricted or prohibited, the tenant is protected. If the lease does not require development, the best evidence of the use intended for the property is the use which the tenant is making of it.

\section{Subsection (d)-The Position of the Landlord}

The landlord's rights are governed by the same rules as are applicable to other owners of open-space land. $\mathrm{He}$ is entitled to compensation in the amount by which the owner's guarantee apportioned to his interest exceeds the net proceeds received by him at a public sale. $\$ 303(b)$. He may claim damages under $\S 302$, but since his claim for the loss occasioned to existing-use value is confined to the present worth of such loss postponed over the period of the lease, and since the regulations are expected to have minimal effects on existing uses, his claim would be small, particularly under a long-term lease. He may claim compensation only upon public sale of his reversionary interest. $\S 303(\mathrm{~b})$.

Two points should be noted in this connection. In his claim for damages under $\$ 302(a)(2)$, the tenant is not restricted, as are other claimants, to the amount of the owner's guarantee apportioned to his interest. Damages paid to the tenant go to reduce the guarantee available for the whole undivided fee interest in the leased property. $\$ 300(d)(2)$. The landlord, on the other hand, is restricted both in his claim for damages, $\S 302(a)$, and in his claim for compensation, $\S 303(\mathrm{~b})$, to the guarantee apportioned to his interest.

The effect of these provisions, taken together with the provisions of subsection (d), can be illustrated by taking the following two situations:

(I) Just prior to the enactment of open-space regulations the rent reserved in the lease was substantially less than the fair rental value of the premises. If the premises had been condemned on the date of such enactment, the tenant would have been entitled to a substantial portion of the unit award. The imposition of the regulations may depress the fair rental value of the premises. When the owner's guarantee comes to be apportioned to the landlord, however, this effect of the regulations is required to be disregarded. $\S 300(c)$. Thus the guarantee allocable to the landlord's interest in the tract is the balance of the guarantee of the whole tract remaining after deducting therefrom an amount equal to the amount by which the value of the unexpired leasehold interest (disregarding the effect of the regulations) exceeds the present worth of the rents reserved in the lease for the remainder of the term.

The tenant, it must be noted, is entitled to claim damages under $\S 302$ without regard to the guarantee available to his interest. Such damages reduce the guarantee available in respect of the whole tract. $\$ 300(d)(2)$. However, if such damages do not exceed the amount of the guarantee for the whole tract which is not allocable to the landlord, the landlord is still left with a guarantee equal to the amount of the unit award payable to him upon condemnation. If the tenant's damages cut into that amount, it follows that the tenant is left paying a rent which is excessive for the regulated property. He should, therefore, be receptive to the landlord's suggestion that he surrender the lease in lieu of claiming such damages.

(2) Just prior to the enactment of open-space regulations the rent reserved in the lease was equal to or more than the fair rental value of the premises. If the premises had been condemned in fee on the date of such enactment, the entire award would go to the landlord. The imposition of the regulations, if anything, will create a greater discrepancy between the rent and the fair rental value of the property. While this effect is to be disregarded, the entire guarantee will still be available to the landlord. If the tenant claims damages, however, under $\S 302$, the amount of such damages will reduce the guarantee available to the landlord. Thus the landlord will be put in a situation 
which is not exactly the same as his situation had the fee been condemned. Nevertheless, he has the advantage of a favorable lease. And the tenant, if he has any claim to damages, must now be paying an excessive rental for the regulated property. Here again he should be receptive to the landlord's suggestion that he surrender the lease in lieu of claiming damages.

The landlord's choice, therefore, in most cases, is a choice between coming to terms with his tenant, by reducing his rent or accepting surrender of the leasehold, or of suffering some impairment of his guarantee.

Leases created in open-space land after the effective date of the declaration of open space may contain appropriate provisions governing the tenant's right to damages under $\S 302(\mathrm{~b})$, in the event of a change in the regulations.

\section{Subsection (e)}

The owner's guarantee established under the Act does not yield perfect results when the land is subject to successive interests. This is apparent from the discussion of the relationship of landlord and tenant. Claims filed by owners of present interests will affect the guarantee available to future interest holders. $\$ 300(d)(2)$.

This subsection authorizes a court of equity to assemble such successive interests for public sale in fee, the proceeds to be reinvested for the benefit of the successive owners as their interests appear. The provision is intended to furnish some protection to successive legal interest holders in their claims to the guarantee. A similar provision is to be found in Ill. AnN. Stat. ch. 22, $\S 50$ (Smith-Hurd 1958).

\section{$\S 304$. Government Acquisition of Property Interests in Open-Space Area}

A political subdivision may acquire, by gift, purchase (at a public or private sale), or condemnation, any property interests in the openspace area and may hold, improve, sell, and lease interests in such area consonant with the open-space purpose and the regulations adopted for the area. If such condemnation occurs after the enactment of regulations under $\$ 203$, the amount of compensation payable shall not exceed: (1) the amount of the owner's guarantee established for or apportioned to the interest taken or (2) the fair value of the interest taken subject to the regulations then in force, whichever is greater.

\section{GOMMENT}

In the case of condemnation, this section requires payment of compensation in an amount equal to the guarantee or the fair value of the property at the regulated level, whichever is greater. The compensation payable is not restricted to the guarantee, the purpose being to encourage the market at the regulated level. The provision that the condemner must pay the fair value of the property at the regulated level, if that is greater than the guarantee, is designed to fulfill the promise of the Act that the owner is not only secure in the value of his property existing on the date of enactment of open-space regulations but is entitled to all increments in that value, if any, which accrue to the property at the regulated level. Other provisions designed to have this effect are $\S \S 302(\mathrm{~b})$ and $303(\mathrm{~b})$.

The powers granted under this section may be used to prevent loss to the community resulting from an untimely public sale under $\S 303(\mathrm{~b})$ and, possibly, 
to prevent windfalls resulting to the owner when the property is deregulated. In such cases, the community may purchase the interest of the owner or condemn it at the regulated value or for the amount of the guarantee, whichever is greater, and resell or lease for uses consonant with the open-space purpose. Condemnation in the case of planned deregulation of the property may be justified, particularly where the community has already paid compensation upon the guarantee, on the basis that the increment involved, otherwise accruing to the owner, belongs to the community under the scheme of the Act. Such condemnation is not specifically provided for in the Act, leaving the matter, rather, to the determination of the courts in each particular case.

\section{$\S$ 305. Prorating Owner's Guarantee Upon Subdivision}

Whenever the owner of any tract of open space submits a subdivision plan for the tract to the appropriate planning agency, a copy of the subdivision plan shall be submitted to the Board of Review. Upon notification by the planning agency that the subdivision plan is in accord with the applicable open-space regulations, the Board of Review shall prorate the owner's guarantee established for the tract among the lots to be created by the subdivision plan as provided in $\$ 409$ of this Act and file with the planning agency, and send by certified or registered mail to the subdivision applicant within 30 days of receipt of the notice from the planning agency, a statement of the owner's guarantee assigned to each of the proposed lots, the total of which shall equal the original guarantee. In prorating the original guarantee the Board of Review may consider the sale price of comparable lots following subdivision and shall consider the structures existing on each proposed lot and the natural features of the land in each of the proposed lots.

\section{ARTICLE IV. PROCEDURE}

\section{$\S 400$. Establishing Market Value: Owner's Guarantee}

No later than the date of the enactment of open-space regulations, as provided in $\$ 203$ of this Act, the governing body of the political subdivision shall cause the County Tax Assessor to make a special assessment establishing the value of each tract of land situated in an openspace area in accordance with the principles set forth in $\$ 401$ of this Act.

\section{§ 401. Valuation: Owner's Guarantee}

Each tract of land situated in an open-space area shall be valued, for purposes of establishing the owner's guarantee provided for in $\$ 300$ of this Act, as follows:

(a) There shall be established for each tract the fair value of the tract existing on the date when the open-space regulations were enacted, taking into account the improvements thereon but, except as to interests which are appurtenant to other tracts (whether within the open-space area or without it) and which form part of the value of such 
other tracts, without regard to the separate interests therein, if any, or the encumbrances thereon, if any, existing on such date.

(b) In determining the fair value existing on such date, no account shall be taken of the effect which the enactment of the regulations or of the effect which any indication thereof, whether official or unofficial, might have had upon the value of the property situated in the openspace area, and the fair market value shall be determined as if such regulation or indication thereof had never occurred.

\section{COMMENT}

The "fair value" to be established for each tract as of the date when the regulations come into force is intended to be coextensive in meaning with the "just compensation" which would then be payable were the tract condemned in fee.

Neither enhancement nor depression in value resulting from the expectation that the area will be regulated should be taken into account. United States v. Miller, 317 U.S. 369, 379 (1943); State v. Burnett, 24 N.J. 280, 131 A.2d 765 (1957); Wadsworth v. Manufacturers' Water Co., 256 Pa. 106, 100 Atl. 577 (1917). However, the condemner may be required to pay for the enhancement in value occurring when the precise site of the project is unknown. United States v. Miller, supra at 376-79 (dictum). But statutory provisions denying compensation for such enhancement have been upheld. See Cole v. Boston Edison Co., 338 Mass. 661, 157 N.E.2d 209 (1959) (citing cases).

Section 401, by requiring that each tract be valued "without regard to the separate interests therein" adopts the "unit" valuation approach. In this, the Act adopts the prevailing view of valuation for purposes of eminent domain. See 1 Orgel, Valuation Under the Law of Eminent Domain, § 109 (2d ed. 1953). There are situations in which this approach has been questioned:

(1) Where the injury to the separate interests is less than the injury to the property if held in undivided ownership. This exception to the unit approach was established in Boston Chamber of Commerce v. City of Boston, 195 Mass. 338, 81 N.E. 244 (1907), aff'd, 217 U.S. 189 (1910) (Holmes, J.), which held that the condemner need pay only for the loss occasioned to each interest holder where that loss is smaller than the loss which would have resulted to the owner of the entire interest in the property. This exception to the unit approach is incorporated into the present Act, inasmuch as the community is required to pay only the actual loss resulting to each interest holder.

(2) Interests appurtenant to other property. Interests appurtenant to property, other than the condemned property, are generally valued by reference to the dominant tenement rather than as part of the unit condemned. United States v. Welch, 217 U.S. 333, 339 (1910) (easements); United States v. 11.06 Acres of Land, 89 F. Supp. 852, 860 (E.D. Mo. 1950) (covenants); Flynn v. New York, W. \& B. Ry., 218 N.Y. 140, 112 N.E. 913 (1916) (covenants); Neff v. Pennsylvania R.R., 202" Pa. 371, 380, 51 Atl. 1038, 1039 (1902) (easements). Some cases deny this as a matter of statutory construction. E.g., Herr v. Board of Educ., 82 N.J.L. 610, 83 Atl. 173 (Ct. Er. \& App. 1912) (restrictive covenants). Section 401 , in effect, takes the majority position by requiring that appurtenant interests be valued as part of the dominant rather than the servient tenement.

(3) Landlord and tenant. Considerable controversy exists whether the unit valuation approach is appropriate for the case of landlord and tenant. 
See Hitchings, The Valuation of Leasehold Interests and Some Elements of Damage Thereto, in 1960 Inst. of EMINent Domain Proc. 61. A number of courts have required separate valuation. See Arkansas State Highway Comm'n v. Fox, 230 Ark. 284, 322 S.W.2d 81 (1959); Sowers v. Schaeffer, 155 Ohio St. 454, 99 N.E.2d 313 (1951) (dissenting opinion); Sowers v. Schaeffer, 152 Ohio St. 65, 87 N.E.2d 257 (1949) (concurring opinion). One early case suggests that the "undivided fee" or "unit valuation" approach would be unconstitutional. Mayor of City of Baltimore v. Latrobe, $101 \mathrm{Md}$. 621, 61 Atl. 203 (1905). The overwhelming weight of authority, however, favors the "undivided fee" approach. 4 Nichols, EMINENT Domain $\$ 12.42$ (3d ed. 1951). In a number of states, this valuation approach has been made the subject of statutory declaration. E.g., PA. Stat. AnN. tit. 26, $\$ 44$ (1958).

\section{$\S$ 402. Notice of Assessment [text omitted]}

[Assessor to give notice of valuation by certified or registered mail (or by publication where address is unknown) to all holders of property interests in the open-space area. Notice to set forth right of hearing under $\$ 403$.

\section{COMMENT}

The minimum requirements of notice were recently restated in Walker v. City of Hutchinson, 352 U.S. 112 (1956). It is believed that these requirements are met in this section and $\S 408$ (apportionment of the guarantee).

\section{$\S 403$. Hearings by Board of Review}

(a) Within 30 days after notice is given pursuant to $\S 402$, a holder of a property interest in the open-space area may petition the Board of Review of the political subdivision in which the property is located for a hearing to determine the matters set forth in $\S 401$. The petition shall set forth (1) the description of the tract in question, (2) the interest of petitioner therein, (3) the value established by the County Tax Assessor, and (4) the objections thereto.

(b) [Text omitted]

[Copies of petition to be sent by certified or registered mail to all holders of property interests in the tract in question. Notice to be given by publication to all such holders whose addresses are unknown.]

\section{§ 404. Matters To Be Determined by Board of Review}

The Board of Review shall hear the parties and their witnesses to determine whether the value established for the tract in question is the fair value as defined in $\S 401$ of this Act. At the hearing evidence may be admitted as provided in $\S 405$, and a full record thereof shall be made.

\section{COMMENT}

The procedures providing for the establishment and apportionment of the guarantee are intended to accord with the procedures constitutionally required to be followed in condemnation cases. 
In Port of New York Authority v. Heming, 34 N.J. 144, 167 A.2d 609 (1961), the court reiterated the position taken by a long line of cases, both state and federal, as follows: "No particular form or mode of action is required. All that is essential is that in some appropriate way, before some properly constituted tribunal, inquiry shall be made, on notice, as to the amount of compensation to be paid for the property taken, and when that has been provided the command of due process has been met." $I d$. at 154-55, $167 \mathrm{~A} .2 \mathrm{~d}$ at 614 .

\section{$\S 405$. Admissibility of Evidence of Value}

At the hearing held by the Board of Review it shall be competent for witnesses, when duly qualified, to testify as to their opinion of the market value of any tract of land situated in the open-space area, subject to the rule stated in $\$ 401$ (concerning the effect of adoption of the declaration of open space and regulations thereunder). The Board of Review shall be entitled to consider all returns and assessments of capital value for local taxation made or acquiesced in by the owner or owners of the tract being valued.

\section{COMMENT}

The cases are in agreement that, at the hearing to determine compensation, evidence of assessed valuation made for tax purposes is inadmissible on the question of market value. City of Chicago v. Harrison-Halsted Bldg. Corp., 11 Ill. 2d 431, 143 N.E.2d 40 (1957); Berger v. Public Parking Authority, 380 Pa. 19, 109 A.2d 709 (1954). But statutes providing to the contrary have been upheld. Bennett v. Brookline Redev. Authority, 173 N.E.2d 815 (Mass. 1961). The valuation to be made by the County Tax Assessor under $\$ 400$, however, is a special assessment governed by the principles of valuation set forth in $\S 401$. Section 405 provides that evidence of returns made or acquiesced in by the owner is admissible. There are a number of cases supporting this exception as a matter of common law. See United States v. Certain Parcels of Land, 261 F.2d 287 (4th Cir. 1958) (dictum) (evidence may be introduced to impeach the landowner); Welton v. Iowa State Highway Comm'n, 211 Iowa 625, 233 N.W. 876 (1930) (evidence may be brought out on cross-examination of landowner).

\section{$\S 406$. Valuation Becomes Final [text omitted]}

\section{§ 407. Appeals From Determination of Board of Review}

Within thirty days after an order of the Board of Review, confirming, modifying, or changing the valuation established by the County Tax Assessor, the petitioners at such hearing may appeal to the [trial court of general jurisdiction]. . . The Court shall . . .

\section{COMMENT}

The valuation in eminent domain may initially be set by any arm of government, provided there is an appeal to the courts. See, e.g., Pierce v. City of Bangor, $105 \mathrm{Me}$ 413, 74 Atl. 1039 (1909); Ligat v. Commonwealth, $19 \mathrm{~Pa}$. 456 (1852) (state constitution expressly secures right to appeal); Wilburn v. 
Raines, 111 Va. 334, 68 S.E. 993 (1910). Thus, there can be little objection to the procedure of $\S 400$, requiring initial valuation by the County Tax Assessor, when combined with $\S \S 403-05$ (hearing before the Board of Review) and this section (appeal to the courts).

The scope of review is left to be determined in the light of the constitutional requirements existing in the jurisdictions adopting this Act. In the majority, jury trial is not required. See, e.g., Long Island Water Supply Co. v. Brooklyn, 166 U.S. 685 (1897); Port of New York Authority v. Heming, 34 N.J. 144, 167 A.2d 609 (1961); 1 ORgel, Valuatron UNDER tHE LAW OF EMINENT Domain $\$ 8$ (2d ed. 1953). In such jurisdictions, a limited review confined to the record made before the Board of Review would seem to suffice. See Crane v. Hahlo, 258 U.S. 142 (1922); Huber v. Steel, 14 Del. Ch. 302, 125 Atl. 673 (Ch. 1924). Full trial de novo would have to be granted where, as in Pennsylvania, the state constitution secures the owner's right to appeal and to a jury trial upon such appeal. PA. Const. art. $16, \S 8$.

\section{$\S$ 408. Procedure for Apportionment of Owner's Guarantee Under $\S \S 302$ and 303 [text omitted]}

[Owners claiming damages under $\S 302$ or compensation under $\S 303$ where the owner's guarantee must be apportioned shall petition the Board of Review; copies of petition to be sent to other interested property owners; hearing to conform to provisions of $\$ \S 40406$. Appeal shall lie in accordance with $\S 407$.]

\section{§409. Procedure for Prorating Owner's Guarantee Upon Subdivision [text omitted]}

[Owner shall submit reasonable scheme for allocation which shall be followed unless there is objection either on the part of other owners or on the part of the planning agency; if there is objection, a hearing shall be held in accordance with $\$ \S 404$ and 405 , with certain exceptions.] 